\title{
Adolfo de la Huerta: imágenes de su penúltima rebelión (1923-1924)
}

Pedro Castro Martínez

UAM-IZTAPALAPA

Este trabajo estudia episodios relevantes de la actuación de Adolfo de la Huerta durante la rebelión de 1923-1924.

Entre ellos se incluyen algunos que provocaron agrias controversias, como fue su supuesta participación en el asesinato de Felipe Carrillo Puerto y su salida a Estados

Unidos. Tales momentos ofrecen una panorámica del movimiento a partir de quien ejerció un papel principal de liderazgo.

L os incidentes derivados de la sucesión del general Álvaro Obregón marcaron el distanciamiento paulatino entre el presidente de México y su secretario de Hacienda, Adolfo de la Huerta, hasta su completa ruptura en septiembre de 1923. Dos meses después éste aceptó su candidatura a la presidencia de la república, al poco tiempo de que el gobierno arremetiera en su contra inputándole graves cargos de corrupción e ineficiencia y de que llegara al atentado personal en tres ocasiones. Las versiones sobre la realidad de estos acontecimientos se muestran en La rebe- lión sin cabeza, de Alonso Capetillo y El último caudillo, de Monroy y Bautista en un extremo, y las Memorias de don Adolfo de la Huerta, según su propio dictado de Roberto Guzmán. Pero fue el caso de que el candidato presidencial De la Huerta abandonó la ciudad de México y se dirigió a Veracruz, donde acabó siendo el hombre principal en la revuelta que estalló en diciembre de aquel año. Es menester señalar que los trabajos de Capetillo y Monroy fueron elaborados como una suerte de "libros blancos" sobre la disidencia y la rebelión, con un notable sesgo gobiernista, si bien contienen 
una buena cantidad de detalles y documentos que no pueden ser ignorados. La obra de Guzmán, por su parte, es igualmente valiosa en los mismos términos que los anteriores, aunque está teñida de las limitaciones propias de la pasión partidaria. Desde luego, escapa a los propósitos de este ensayo marcar los aciertos y errores de las obras mencionadas, cuyos autores vivieron de cerca la malhadada rebelión delahuertista, pero no recibieron el beneficio de la abundante documentación de carácter público y privado actualmente disponible.

Este trabajo ilustrará pasajes virtualmente desconocidos sobre el desempeño del líder de la rebelión que tomó su apellido, en donde pesarían -para mal de su causa-sus propios dilemas morales, que fueron freno y arranque de su actividad a lo largo del movimiento. Esta ambivalencia, de entrada, parecía negarle la capacidad de construir un frente armado unido contra el gobierno central. No obstante, fue capaz de convocar de diversos modos a una suma multicolor de personajes e intereses diversos. En ella se contaron, entre otros, revolucionarios muy conocidos como Salvador Alvarado, Antonio I. Villarreal, Manuel M. Diéguez, Fructuoso Méndez, Nicolás Fernández, Manuel Chao o Jorge Prieto Laurens. En la lista del primer círculo rebelde se contaban también Rafael Zubarán Capmany y Álvarez del Castillo, así como los generales Aguilar, Estrada, López de Lara, Sánchez, García Vigil, Cesáreo Castro, los Figueroa, los Greene, Enrique Estrada, Rafael Buelna y Nicolás Fernández, por mencionar solamente algunos. Cualquier conclusión definitiva respecto a las tendencias conservadoras del movimiento delahuertista es desacertada, y evocadora del discurso del general Obregón, para quien todos sus enemigos eran "reaccionarios" por definición. En consecuencia, en la elaboración de este trabajo se ha tenido buen cuidado de no hacer generalizaciones acerca de una tendencia ideológica dominante en la rebelión o en la postura del gobierno de entonces. Por lo demás, una consideración de este tipo, oculta lo principal, es decir, que el movimiento fue ante todo producto de una oposición extendida al afán de Obregón de imponer al general Plutarco Elías Calles. En otras palabras, esta rebelión debe ser vista ante todo, como el lado más violento de la lucha por el poder entre grupos y coaliciones en conflicto por hacer prevalecer su proyecto de dominio político. La originalidad del ensayo que presentamos, se nutre, en todo caso, de la información contenida en documentos hasta ahora revelados al historiador, la cual nos condujo, en varias ocasiones, a interpretaciones diferentes a las que aún están en boga, acerca de una época, un suceso y una responsabilidad individual.

La historia militar de la rebelión consistió en éxitos iniciales y fracasos subsecuentes hasta la victoria completa del gobierno, obtenida en buena parte por el apoyo irrestricto de Washington al presidente Álvaro Obregón. En lo que toca a Adolfo de la Huerta, su presencia en territorio nacional se mantuvo hasta la segunda semana de marzo de 1924, cuando salió de Frontera (Tabasco) rumbo a Estados Unidos, con el propósito de fortalecer al mo- 


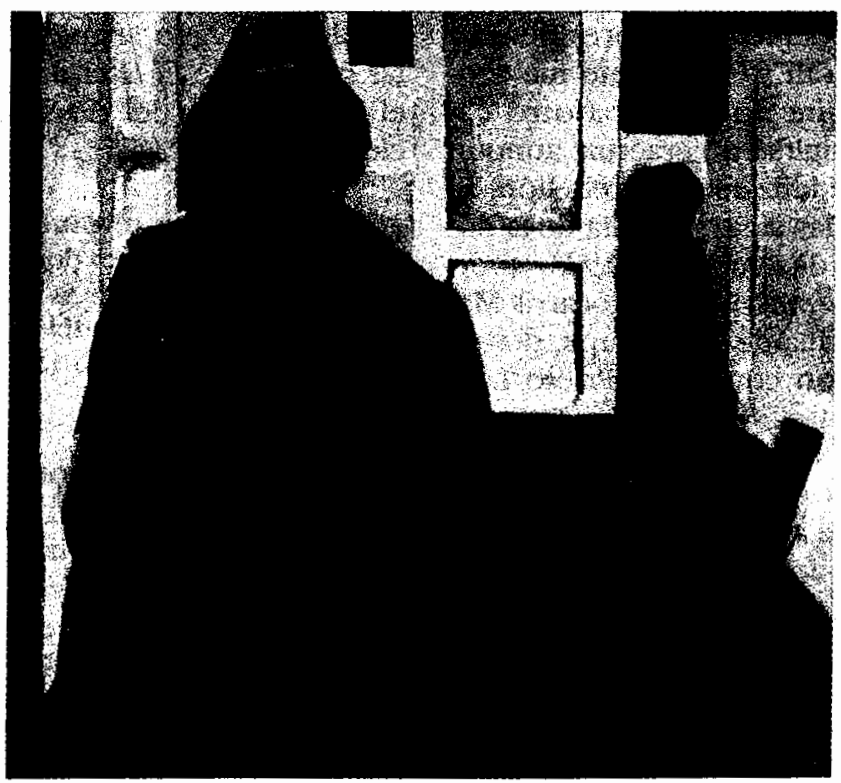

vimiento desde el exilio. En condiciones del más estricto clandestinaje y acosado durante años por el Departamento de Justicia de Estados Unidos, mantuvo viva la llama de la rebelión. En rigor y en contra de un conocimiento histórico insuficiente, las actividades opositoras de Adolfo de la Huerta concluyeron hasta 1928, cuando públicamente anunció su retiro de la actividad política, una vez que supo de la muerte del general Álvaro Obregón.

\section{VERACRUZ Y FRONTERA}

Una suma de elementos tales como la virulencia de los ataques contra la oposición, la seguridad de que el resultado de las elecciones presidenciales serían decididas por el ejecutivo $y$, des- de luego, la convicción de que el recurso a la violencia ofrecía buenas posibilidades, alentó la idea de cooperatistas y militares disidentes de levantarse en armas. El general Guadalupe Sánchez, jefe de operaciones militares en Veracruz, propuso a los cooperatistas que el poder legislativo fuese trasladado a esta entidad, donde se otorgarían las garantías necesarias para su funcionamiento. Asimismo, les manifestó que en un momento dado estaría dispuesto a sublevarse, pero antes debía tener lugar la salida de De la Huerta y partidarios de la ciudad de México. Este, en un primer momento, se negó a abandonar la capital, a secundar rebelión alguna e invitó en cambio a Sánchez a abandonar sus planes. Creía que era lo acertado esperar el desarrollo de los acontecimientos y actuar 
hasta que las elecciones presidenciales se realizaran. ${ }^{1}$ Finalmente fue convencido de que no quedaba otro camino que dirigirse a Veracruz, aunque sin la idea de lanzarse a la rebelión. Él y Zubarán, a las siete y media de la noche del 4 de diciembre de 1923, abordaron un pullman del Ferrocarril Mexicano en la villa de Guadalupe, donde se encontraron con Jorge Prieto Laurens. $^{2}$

Adolfo de la Huerta y sus acompañantes llegaron a Veracruz a las ocho de la mañana del 5 de diciembre de 1923 , donde fueron recibidos festivamente por el general Guadalupe Sánchez. El candidato presidencial mostró disgusto por tal recibimiento porque deseaba llegar a su destino con la mayor discreción. Pidió ser llevado a la casa del diputado Rubén Basáñez, frente a la Aduana y los ferrocarriles, donde habló sólo con Sánchez y Villanueva. ${ }^{3}$ Éstos trataron sin éxito de convencer a De la Huerta de tomar las armas, quien sostenía "que no deberíamos hacerle el juego al gobierno, ya que éste sólo quería que nos precipitásemos en actos subversivos y así incapacitarnos legalmente para la pugna democrática". Para precipitar su adhesión al levantamiento, Jorge Prieto Laurens redactó entonces un plan, "desde Xilitla, S. L. P.", en el que, en su carácter de "gobernador constitucional del Estado Libre y Soberano de San Luis Potosí" desconocía al poder ejecutivo federal y reconocía a Adolfo de la Huerta como jefe supremo de la

\footnotetext{
1 Valadés, "Memorias", p. 1783.

${ }^{2}$ Guzmán, Memorias, 1958, p. 249.

${ }^{3}$ Prieto, México, 1987, p. 421.
}

revolución. Acto seguido, se dirigió a las oficinas de El Dictamen e hizo que el encabezado del diario del 6 de diciembre quedara así:

Estalló aquí la revolución: el general Guadalupe Sánchez desconoce a Obregón y don Adolfo de la Huerta es declarado jefe supremo del movimiento revolucionario. Prieto Laurens lanza la primera proclama. ${ }^{4}$

A la mañana siguiente la maniobra de Prieto Laurens tuvo los resultados esperados. Adolfo de la Huerta se enteró de la nota de El Dictamen, y contrariado habló con Prieto: "¿Con qué derecho toma mi nombre?... usted es un usurpador; usted ha escrito el plan revolucionario sin mi autorización. ¿Quién le ha dado esas facultades?". "Para salvar a usted, de acuerdo con el general Sánchez". Zubarán, quien presenciaba el acto, terció para referir a Prieto lo mal que había hecho, "porque no es usted quien ha de dirigir este movimiento". El increpado rechazó la acusación de indisciplina, mientras

\footnotetext{
${ }^{4}$ Prieto, Cincuenta, 1968, pp. 211-213; Valadés, "Memorias", p 1787. El motivo de la actuación de Prieto, en sus propias palabras, fue que "nosotros, deliberadamente, violentamos los acontecimientos para lograr que don Adolfo de la Huerta, con su gran personalidad que todos le reconocíamos, se decidiera a dar el decisivo y grave paso de romper definitivamente, por medio de las armas, con el gobierno del general Obregón, después de haber agotado los medios pacíficos, democráticos y de convencimiento, ya que nuestro grande e inolvidable amigo, don Adolfo, era un pacifista convencido y creía de buena fe, que vencería a sus enemigos por la razón y la justicia, sin recurrir a la fuerza. Entrevista a Jorge Prieto Laurens, 27 de octubre de 1981.
} 
Zubaran le decía a De la Huerta que ya nada se podía remediar y que era hora de hacer un plan a suscribir por todos los seguidores adolfistas. Acto seguido, mientras Zubarán redactaba el Plan de Veracruz y el país se enteraba de la sublevación de Sánchez, De la Huerta se preparaba para asumir la jefatura de la revolución. ${ }^{5}$ Jesús Villanueva Garza y Prieto Laurens, por su parte, se hicieron cargo de la administración civil. ${ }^{6} \mathrm{El} 6$ de diciembre por la tarde, la Marina del Golfo se sumaba a la rebelión y salía en distintas direcciones una proclama de Sánchez en la que, en unión del comandante general de la Marina del Golfo, Hiram Toledo y del jefe de infantería, Alfonso Calcáneo Díaz, desconocía al presidente Obregón, afirmando tener 22000 hombres a sus órdenes. ${ }^{7}$

Un día después, el periódico veracruzano daba a conocer la "Declaración revolucionaria de Adolfo de la Huerta", que denunciaba en sus considerandos el propósito del poder ejecutivo de imponer la candidatura del general Calles,

echando mano de todos los recursos del erario, de todos los empleados de la administración pública y principalmente del ejército, como instrumento decisivo y de fuerza, queriendo corromper así su preclaro origen revolucionario y noble espíritu de la institución.

Asimismo, condenaba "las violaciones a la soberanía del pueblo", en los

5Valadés, "Memorias", p. 1787.

${ }^{6} \mathrm{Ibid}$., p. 1786; Prieto, Cincuenta, 1968, pp. 209-210.

${ }^{7}$ Prieto, Cincuenta, 1968, pp. 213-214. casos de las gubernaturas de San Luis Potosí, Michoacán, Coahuila y Nuevo León, igual que en las elecciones del poder legislativo efectuadas en 1922 , cuando "se consumó de la manera más descarada la violación al principio de la efectividad del sufragio". También declaró que Obregón no sólo había pisoteado la soberanía de los poderes legislativo y judicial, sino que había usado su

inmenso poder para encadenar las libertades, convirtiéndose en líder político de la candidatura impopular de Calles, con la idea de asegurar para sí mismo una relección posterior, que la Nación rechaza y que nuestra ley condena.

En consecuencia, el manifiesto desconocía al general Obregón en su carácter de presidente de la república, así como a los miembros del poder legislativo y judicial. $^{8}$

De inmediato se dieron las primeras batallas. La primera y más importante sublevación fue la del general Enrique Estrada en Jalisco, a quien el general Salvador Alvarado, por instrucciones de De la Huerta, invitó a pronunciarse en su favor. ${ }^{9}$ Dos días

\footnotetext{
${ }^{8}$ El plan se encuentra glosado en Dulles, Ayer, 1977, pp. 201-202. Las cursivas son mías.

9 "Narración de los hechos por el general brigadier Calixto Ramírez Garrido, quien fungió como jefe del Estado Mayor del general Alvarado", Ramírez, General, p. 136. La versión de José C. Valadés, fue que la invitación la hizo el general Guadalupe Sánchez. Relata que Estrada respondió que le rogara "interrogar a [...] De la Huerta $[\ldots]$ si al aceptar la jefatura del movimiento revolucionario en la república, ha puesto por un lado los intereses político-electorales para asumir la gran responsabilidad de jefe de
} 
después de este pronunciamiento, el general Estrada insistió con los generales Fortunato Maycotte y Manuel García Vigil, jefe de las operaciones militares y gobernador de Oaxaca, respectivamente, quienes ya se habían rebelado contra el gobierno, para que reconocieran también a De la Huerta como jefe. Otros levantados de primer momento fueron los coroneles Arnáiz en Aguascalientes y Vallejo en Campeche, así como los generales Figueroa en Guerrero, Pineda en Chiapas, López de Lara en Tamaulipas y Chao en Chihuahua. Luego vinieron los avances iniciales: el general Villanueva Garza cayó sobre Jalapa y avanzó hasta las goteras de San Marcos, mientras que los generales Antonio I. Villarreal y Cesáreo Castro, hacían lo propio sobre Puebla, quedando en condiciones de avanzar sobre la capital de la república.

Los líderes políticos en Veracruz exhibieron desde un principio sus hondas diferencias. Los primeros alineamientos fueron el de Zubarán (con una fuerte influencia sobre De la Huerta) y el de Antonio I. Villarreal, Prieto Laurens y Jesús Villanueva Garza. Dos elementos influían gravosamente èn la difícil circunstancia en que se encontraban: los viejos rencores no superados, como eran los que cordialmente se profesaban Zubarán y Prieto Laurens; $y$, peor aún, los celos y temores

la revolución [...] A lo que De la Huerta mismo respondió: "he hecho un paréntesis en mi carácter de candidato para asumir mi nueva responsabilidad", contestación que no satisfizo a Estrada, Valadés, "Rebelión". El 6 de diciembre Estrada rompió públicamente con Obregón y se declaró levantado en armas, Taracena, Verdadera, 1962, p. 162. compartidos de que alguno de los líderes adquiriese relieve sobre los demás. De la Huerta, abrumado por las muchas presiones propias de la lucha política y militar, y viviendo una suerte de entrañamiento personal frente a situaciones no deseadas ni previstas, fallaba en conseguir el equilibrio entre sus aliados. De aquí partieron resoluciones que empeoraban las de suyo insuperables divisiones. Su inclinación hacia Zubarán, por ejemplo, lo llevaría a llamar a Villarreal a abandonar sus preparativos para el avance hacia México, a fin de incorporarlo a su gobierno rebelde como alto comisionado de Agricultura y Fomento. O cuando, capturado el puerto de Tuxpan, De la Huerta nombró a Jorge Prieto Laurens re. presentante de la rebelión en la región petrolera, que fue interpretado como un movimiento provocado por Zubarán para enviarlo lejos. ${ }^{10}$

Jorge Prieto regresó a Veracruz cuando fuerzas obregonistas amenazaban las posiciones rebeldes en Estación Esperanza. De la Huerta le pidió que convenciera a los jefes de Tabasco de enviar sus contingentes al amenazado puerto. Prieto entonces consiguió en Frontera que el rebelde general Se-

${ }^{10}$ Las relaciones entre Zubarán y Prieto Laurens, desde los primeros días de Veracruz, fueron difíciles. "Zubarán simuló amistad y estimación para mí -decía Prieto-pero muy pronto aparecieron sus bajas pasiones y del menor pretexto procuró aprovecharse para impresionar desfavorablemente contra mí a nuestro jefe [...] habiéndose propuesto hacerme fracasar en todas las empresas [...]". Carta de Jorge Prieto Laurens (Houston) a Alfonso Gómez Morentín, El Paso, 26 de septiembre de 1924, p. 1 en Archivo Familia De la Huerta (en adelante AFDH). 


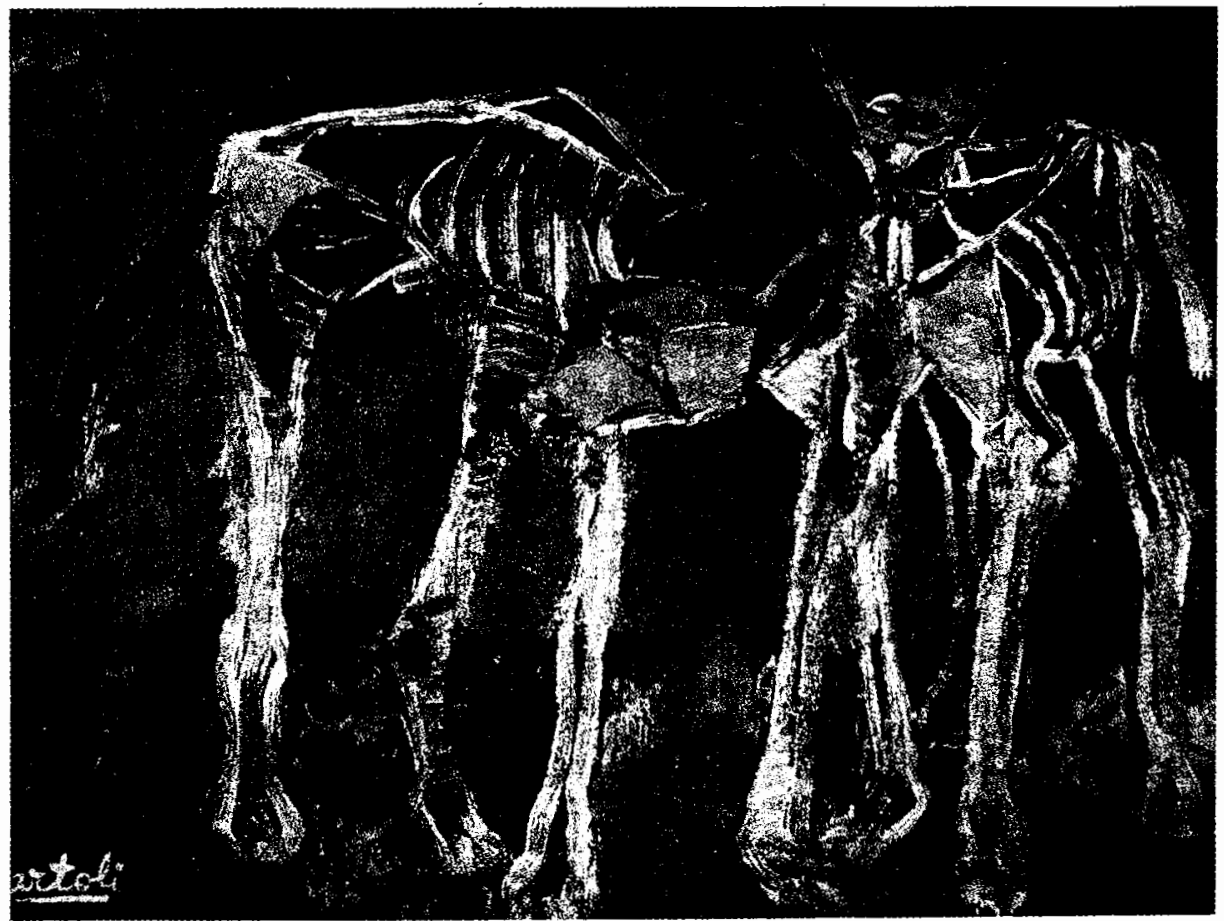

govia se embarcase con sus tropas con ese destino, pero advirtió que entre ellas viajaban obregonistas rendidos en Villahermosa, al mando del coronel Pedro León. Pidió autorización a De la Huerta para desarmarlas y enviarlas a la Huasteca potosina para distraer al enemigo de aquella región, pero en cambio recibió su orden terminante de remitir todas esas fuerzas con sus mismos jefes y oficiales a Veracruz. Desobedeciendo instrucciones, el general Segovia y Prieto pudieron desarmar a 2.000 soldados federales en alta mar y enviarlos a Tuxpan, pero antes de llegar De la Huerta ordenó que el barco regresase a Veracruz, donde los federales fueron rearmados y aceptados sus servicios para reforzar al general Guadalupe Sánchez. ${ }^{11}$ Pedro León y subordinados, al desembarcar en Veracruz protestaron su adhesión a De la Huerta, como antes lo habían hecho los federales Vicente L. González y Miguel Henríquez Guzmán. A éstos De la Huerta les dio dinero y pasajes para que se trasladaran al norte de México a través de Estados Unidos, a fin de secundar en esa región al movimiento rebelde, cosa que prometieron ha-

11 Valadés, "Memorias", p. 1789. Los detalles del episodio se encuentran en Prieto, Cincuenta, 1968, pp. 238-240. 
cer. ${ }^{12}$ Pero cara costó la confianza depositada en ellos. Las tropas de Tabasco, al mando del general León, atacaron a Sánchez por la retaguardia y así causaron la primera derrota militar del delahuertismo.

El desastre de Estación Esperanza, del 28 de enero de 1924, fue el principio del derrumbe paulatino del movimiento. En esos días llegó el general Cándido Aguilar a Veracruz, procedente de San Antonio, a ponerse bajo las órdenes de la rebelión. ${ }^{13}$ Los motivos de Aguilar no dejan de ser extraños: con el movimiento de Agua Prieta y la muerte de Carranza, tenía razones poderosas para detestar por igual a los tres sonorenses. Con el general Francisco Murguía y otros carrancistas conspiró desde su refugio texano én contra de los gobiernos de De la Huerta y Obregón. En la lógica más elemental, estas experiencias obraban en contra de cualquier alianza hacia uno y otro bando, porque eran igualmente sus enemigos. ${ }^{14}$

Apenas saltó a tierra, Aguilar fue designado jefe del ejército de Oriente, dado que se ignoraba el paradero de Guadalupe Sánchez, derrotado en Es-

12 Carta de Jorge Prieto Laurens a Miguel Palacios Macedo, México, 22 de noviembre de 1951 en Archivo Miguel Palacios Macedo (en adelante APM).

${ }^{13}$ Corzo, González y Skerrit, Nunca, 1986, p. 255 .

${ }^{14}$ Su postura la explicaría meses después, a través de su llamado "Manifiesto de San Antonio", del 23 de septiembre de 1924, cuando manifestó que su participación en la rebelión se debía a un acto de "defensa de la soberanía vulnerada" por el auxilio estadunidense a Obregón. Manzur, Revolución, 1972, p. 196. peranza. El cargo, sin embargo, le fue retirado a las 24 horas cuando el ausente dio señales de vida. Con De la Huerta al frente de una junta de militares y civiles en San Juan de Ulúa, para decidir qué hacer después de lo acontecido en Estación Esperanza, se acordó que la Marina del Golfo y los restos de las fuerzas tabasqueñas se trasladaran con los civiles a Frontera, Tabasco. ${ }^{15}$ En ese momento, el ejército federal tenía las puertas abiertas para tomar el puerto de Veracruz, por lo que la situación de los rebeldes se volvió insostenible. El 5 de febrero de 1924 dio comienzo la desordenada evacuación del lugar, con destino a un lugar más seguro. Frontera era el mejor camino, porque la mayoría de los militares tabasqueños habían abrazado con firmeza la rebelión. En su salida por mar, acompañaron a De la Huerta el general Aguilar (nombrado ahora jefe de la tercera zona militar que comprendía los estados de Tabasco, Campeche, Yucatán y Territorio de Quintana Roo), Zubarán, Palacios Macedo, Rodolfo Brito Foucher, Calcáneo Díaz y los generales Segovia, Vidal y Vivanco con sus fuerzas de protección. ${ }^{16}$ Antonio I. Villarreal y Jorge Prieto Laurens, por su parte, fueron los últimos en evacuar el puerto, llevando un barco abarrotado de hombres mal armados, que desembarcaron en Tuxpan, con el propósito de unirse al general Lárraga. ${ }^{17}$

La estancia de De la Huerta en Frontera se inició el 8 de febrero, y los acon-

\footnotetext{
${ }^{15}$ Prieto, Cincuenta, 1968, p. 240.

${ }^{16}$ Ibid., p. 241.

${ }^{17}$ Ibid., p. 242.
} 
tecimientos principales tuvieron que ver con el manifiesto del día 20 de este mes, los conflictos internos y una necesidad de dar nuevos bríos al movimiento, a pesar de que algunas plazas todavía se mantenían en el sureste. Para esas fechas el apoyo estadunidense al gobierno de Obregón era patente y causaba efectos nocivos sobre la rebelión. Embargo de armas, bloqueo de puertos del golfo, tránsito franco a tropas obregonistas por territorio estadunidense, créditos, armamentos y parque, aviones y pilotos, apoyo diplomático, entre otros, contribuyeron en una medida sensible a quebrar la espina dorsal del movimiento. Washington pagaba bien la parte que le correspondía, por así decirlo, por la aprobación de los Acuerdos de Bucareli por el gobierno de Obregón, que convirtieron en letra muerta al artículo 27 constitucional. En otras palabras, Estados Unidos se inclinó por quienes, en su momento, mejor garantizaban los intereses del poderoso sector petrolero que tanta presión ejerció sobre México desde 1917.

A fin de fortalecer la moral maltrecha, los alzados abrieron un nuevo capítulo en su lucha, presentándola ahora como de la "defensa de la soberanía y la independencia de la patria". Adolfo de la Huerta, establecido en la nueva capital rebelde, acusó al general Álvaro Obregón de ser un traidor que había ofrecido en venta la soberanía nacional "al más poderoso gobierno extranjero, a precio de barcos de guerra, aeroplanos, carabinas, proyectiles y dinero". Un delito de lesa patria fue denunciado en sus más duros términos en contra de sus antiguos aliados:
Cuando apenas comenzábamos a merecer el respeto y la consideración de los pueblos libres con el mantenimiento inquebrantable de una política digna y doblemente nacionalista, Obregón traiciona a su patria, $y$ traiciona a su raza, implorando, con ademán humillante y cínico, y obteniendo ayuda de un gobierno extranjero para perpetuarse en el poder y para iniciar con Plutarco Elías Calles una era de atentados y crímenes sin nombre. ${ }^{18}$

No importa que Obregón adquiera cañones de gobiernos extranjeros para derramar sangre de mexicanos [...] No importa que Obregón alquile pilotos estadunidenses para que desde sus aviones asesine ancianos, mujeres y niños... Todos los que anhelen un porvenir de libertad para sus hijos, empuñarán las armas contra los traidores,

rezaba la proclama de De la Huerta. ${ }^{19}$ Dio la impresión de que podría despertar sentimientos negativos hacia los

${ }^{18}$ De la Huerta, "Manifiesto", febrero 20 de 1924, en AFDH.

${ }^{19}$ En términos semejantes se expresó el general Alvarado en un manifiesto sin fecha titulado "Al esforzado ejército nacional revolucionario y a los habitantes todos de la república", dirigido a sus soldados en Colima, después de la pérdida y evacuación de Guadalajara el 11 de febrero de 1924. El citado general denunció severamente al presidente, afirmando que "él había empleado extranjeros como pilotos de sus aeroplanos para asesinar mexicanos en su propio suelo". Vicecónsul en Manzanillo, Aguirre a Hughes, 15 de febrero de 1924, U. S. National Archives, Washington (NAW), 812.00/27104. Al poco tiempo, el 23 de febrero, Alvarado saldría acompañado por el cónsul estadunidense George A. Bucklin a Vancouver desde Acapulco, en un barco holandés después de haber escapado de Manzanillo. Pangburn a Hughes, Acapuico, 23 de febrero de 1924, en NAW, 812.00/27044. 
estadunidenses en México. Fiel a su línea de no antagonizar con ellos, De la Huerta precisó el contenido de su llamado en términos de condena a la "antipatriota" actitud de Obregón, pero también de respeto irrestricto a los derechos de los ciudadanos de los Estados Unidos en México, a través de un telegrama circular a los jefes militares, gobernadores y otras autoridades. ${ }^{20}$ Esta comunicación tuvo "el efecto psicológico natural de cristalizar el sentimiento revolucionario en Yucatán en favor de De la Huerta", afirmaría el cónsul estadunidense, O. Gaylord Marsh. Éste notó, asimismo, un "ligero" sentimiento de hostilidad contra Estados Unidos, entre la "mejor gente" de la península, que no atinaba a entender cómo este país podía ayudar a forzar un regreso del socialismo carrillopuertista a Yucatán. Se llegó a pensar lo peor en el caso de una victoria obregonista, circunstancia en la que "los americanos estarían en peligro". 21

\section{LOS INCIDENTES DE LA SALIDA}

\section{A ESTADOS UNIDOS}

La situación que se vivía en Frontera empeoraba día con día, por el aislamiento internacional y las amenazas de descomposición del movimiento, bajo la presión de los avances gubernamentales en varios frentes del país.

${ }^{20}$ Citado en inglés en R. L. Rankin al Secretario de Estado, Frontera, 23 de febrero de 1924, en NAW, 812.00/27075.

${ }^{21}$ Cónsul en Progreso O. Gaylord Marsh a Hughes, 27 de febrero de 1924, en NAW, 12.00/ 27086.
La idea de una salida del jefe supremo, de Frontera, se fortalecía en la medida en que su vida peligraba por las disensiones internas, y porque se llegó a pensar que en Estados Unidos podía desempeñar un papel relevante. Tal idea partió del doctor Peter L. Greene (médico tabasqueño residente en ese país) y sus hermanos los generales, y en su favor convocaron entonces al resto de los dirigentes en Frontera para hacer ver a De la Huerta la urgencia de que saliese hacia Washington. Él en un principio no comulgaba con el proyecto, porque su viaje podía malinterpretarse y resultaría desalentador para las fuerzas delahuertistas. Pero en una segunda junta con los militares, ya con la amenaza de la defección de una parte de la Marina del Golfo, De la Huerta acordó salir del país a la brevedad, y los líderes militares y civiles en pleno acordaron hacer público su respaldo a su jefe supremo en esta decisión. Los tripulantes del cañonero Zaragoza, por su parte, se dirigían a Frontera después de deponer a su comandante Morel, por lo que optó por embarcarse y ordenar se diera lastre al vapor Tabasco, no sin antes dictar sus disposiciones con respecto a la jefatura suprema en el puerto, que recayó en el general Cándido Aguilar. ${ }^{22}$ El jefe partió de

${ }^{22}$ Sobre la salida de De la Huerta de Frontera, véase Taracena, Historia, 1976, pp. 414415. Detalles de la salida de De la Huerta de Frontera se encuentran en Guzmán, Memorias, 1958, pp. 267-272; Rankin a Hughes, 12 de marzo de 1924, en NAW, 812.00/27108; Cónsul Marsh a Hughes, 27 de marzo de 1924, en NAw, 812.00/27153. En respuesta a la acusación de Prieto Laurens, ya en el exilio, en el sentido de que "había huido" de México, así respondió De 


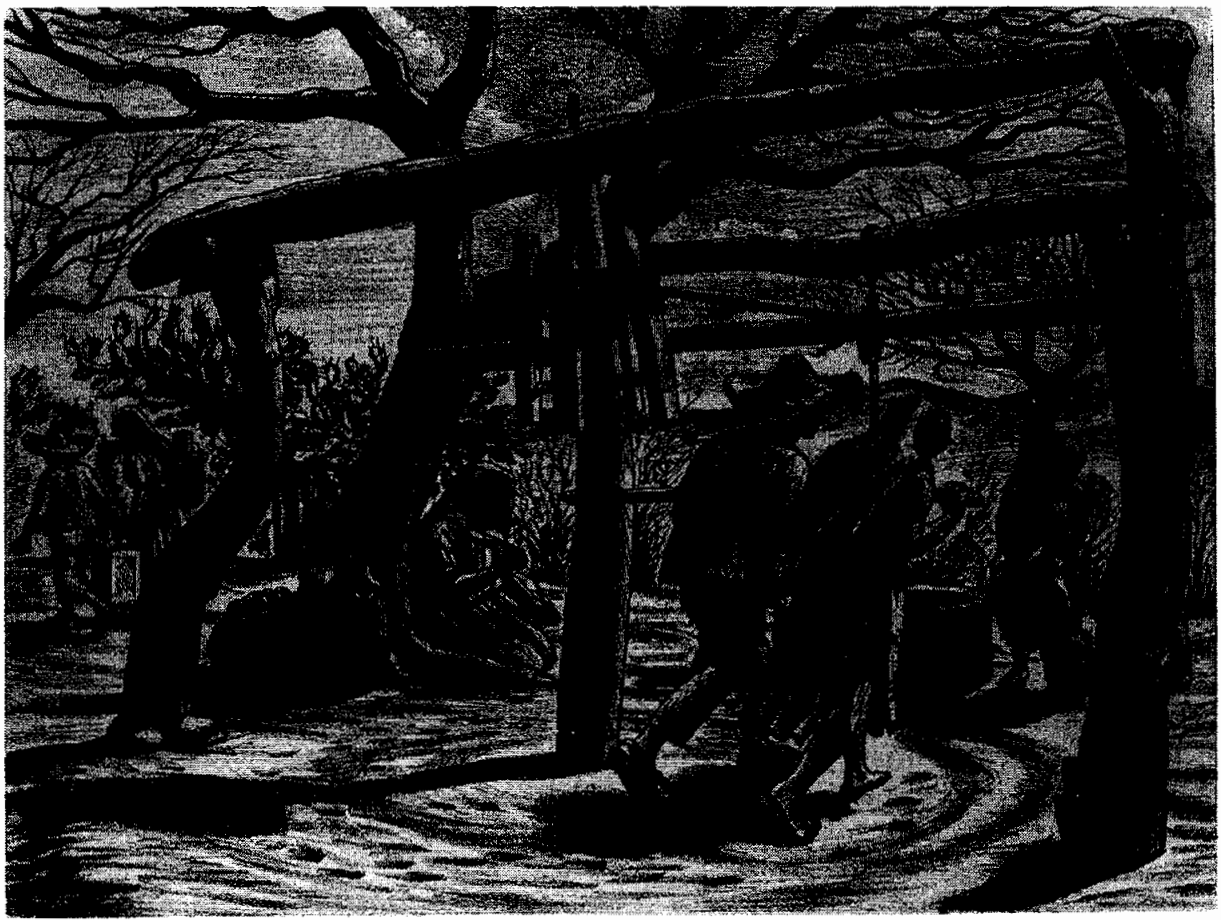

Ciudad del Carmen hasta Bahía Honda, Cuba, al oeste de Ia Habana, después de burlas al buque perseguidor. Continuó hacia Cayo Hueso, Florida, don-

la Huerta: "Si encabecé el movimiento de 20 y si tuve la decisión de lanzarme a la lucha en 23 sin contar con previa organización para aquel movimiento, ¿cómo iba a "huir" del territorio dominado ampliamiente por mis fuerzas, como estaban los estados de Tabasco, Campeche y Yucatán y el territorio de Quintana Roo en los momentos que vine a hacer mi gestión a este país? Para salir de huida tenía más a la mano las fronteras de Guatemala, cuyo gobierno era más imparcial que el de Estados Unidos. Tenía también como refugio el territorio inglés limítrofe a Quintana Roo.", La Opinión, 28 de septiembre de 1927 . de se internó a territorio estadunidense con un pasaporte falso a nombre de Raúl Pérez Heredia. ${ }^{23}$ A continuación, los líderes militares y civiles en Tabasco redactaron un manifiesto que exponía las razones políticas de esta salida, documento importantísimo hasta ahora ignorado por los historiadores de ese episodio (véase Apéndice).

La designación de Aguilar como jefe supremo interino se hizo en contra de la opinión de la mayoría de los jefes militares y civiles porque, por encima de él, se encontraba el general Salvador Alvarado, de quien se tenía noticia

${ }^{23}$ Taracena, Verdadera, 1992, p. 417. 
que estaba en Estados Unidos. Poco antes de la salida de De la Huerta se disgustó con Aguilar por "alguna mala información recibida de él", en el sentido de que estaba en secreto acuerdo con los marinos declarados en contra del movimiento. Sospechaba (y quizá acertaba) que el comandante Hiram Toledo, jefe del Estado Mayor del general Cándido Aguilar, era el cerebro discreto de la rebeldía de un sector de la Marina del Golfo contra el capitán Calcáneo, quien estaba al frente de ella durante el movimiento. ${ }^{24}$ Aguilar negó su participación en esta maniobra y las cosas se aclararon. "Una vez enmendado el error", De la Huerta le señaló que si no conseguía regresar a Tabasco, iría a Sonora a establecer allá el gobierno provisional, y que lo podría necesitar en ese momento. El general Aguilar aceptó el puesto en tanto llegaba Salvador Alvarado. De la Huerta le anticipó que Alvarado sería su sustituto,

por las muchas simpatías que ahí tenía: [por] su habilidad como militar y sus reflejos favorables en Estados Unidos, por la fuerte propaganda que en su favor se había hecho en la época que de-

24 "La maniobra corrió con éxito. Calcáneo fue desconocido como jefe y de pasada, De la Huerta, jefe supremo de las fuerzas de mar y tierra...". Hiram Toledo atribuye como causa única de la salida de De la Huerta de Frontera la defección de la Marina del Golfo que echaba por tierra la última esperanza del triunfo rebelde. "Informe de Hiram Toledo, ex capitán de navio de la armada al señor general de División Arnulfo R. Gómez, jefe de la guarnición de la plaza y de las operaciones militares en el valle de México", 27 de agosto de 1926, en López, "Recuerdos", 1954, p. 29. fendió la reguladora [del Henequén] contra la Ley Shermann...

Aguilar convino en ello, e incluso sugirió que si era necesaria su salida del territorio nacional para el buen entendimiento con Estados Unidos no debía vacilarse y que estaba dispuesto a ir a América del Sur como representante del movimiento. ${ }^{25}$

Ya en el exilio, De la Huerta le comentó a Zubarán que con el tiempo Aguilar se olvidó de lo dicho y que "sintiendo renacer pasados rencores", le enderezó una "furibunda filípica". Agregó que al momento del triunfo le pondría al tanto "de los acontecimientos que estuvieron a punto de desarrollarse y que debido a la providencia (que ha sido nuestra aliada) no dieran al traste con nuestra pobre humanidad". ${ }^{26}$ La última parte es difícil de descifrar, pero al menos es reveladora de que las tensiones entre De la Huerta y Aguilar, antes de salir de Frontera, llegaron a un punto peligroso. La salida del primero desató de inmediato los más encontrados rumores: en un principio corrió que se encontraba enfermo y luego que Aguilar, por motivos desconocidos, había dado un golpe contra De la Huerta. Inquirido por correligionarios acerca de tales especies, así respondió don Cándido:

Me he enterado con pena de la extraña sospecha que ustedes han hecho recaer en el elemento militar al suponer que se ha cometido una deslealtad o trai-

25 Guzmán, Memorias, 1958, pp. 271-272.

${ }^{26}$ Carta de De la Huerta a Zubarán, 26 de mayo de 1924, en Monroy, Último, 1924, pp, 124-125. 
ción al jefe supremo de la revolución. Señor De la Huerta viose obligado a retirarse por unos días para descansar dejándome como encargado de atender y resolver todos los asuntos que son la competencia de la suprema jefatura. El cansancio cerebral de nuestro jefe era tal que, si no se hubiera resuelto a abandonar por unos días sus arduas labores, se hubiera incapacitado para seguir despachando y resolver graves problemas [...]. ${ }^{27}$

Tiempo después, el "cansancio cerebral" de De la Huerta fue convertido por Aguilar en locura. Refiere Prieto Laurens que en las oficinas de la Comandancia Militar, Aguilar le confesó que él mismo había puesto los medios para que De la Huerta saliera del país. ${ }^{28}$ Tal comentario fue conocido por el citado autor Capetillo, que lo convirtió en capítulo de su afamado libelo. Mientras De la Huerta partía hacia el horizonte, en México, el divisionario Aguilar se ponía al frente de la revolución. Entre sus primeras disposiciones estuvo convocar a una junta militar a los principales jefes militares y civiles tabasqueños, con el objeto de acordar

${ }^{27}$ Telegrama del general Cándido Aguilar a correligionarios, s.f., en APM. "Profundamente deploramos extraña interpretación dio usted a nuestras preguntas sobre salud, señor de la Huerta, y situación ésa por que nunca hemos dudado ni pensado siquiera pudiera dudarse de la lealtad de usted y sus dignos subordinados[...]Rogámosle atentamente nos transmita informes tenga salud señor De la Huerta". Respuesta de correligionarios al general Aguilar, s.f., en APM.

${ }^{28}$ Valadés, "Memorias", p. 1792. Esta versión fue escuchada, por Alonso Capetillo, quien la recreó en el subcapítulo "Estados", pp. 187193 de su libro, Rebelión, 1925. algunas medidas urgentes. ${ }^{29}$ Pero pronto llegó a Frontera el general Alvarado, expidiendo sus propias órdenes, con su nombramiento como jefe supremo de la revolución firmado por De la Huerta en Nueva York. ${ }^{30}$ Mientras el general Cándido Aguilar y el gobernador Manuel Antonio Romero visitaban los límites de Veracruz y Tabasco, tuvieron conocimiento del arribo del general Alvarado a Frontera. Aguilar se sintió ofendido porque pensaba que le sustituiría por deslealtad y protestó ante De la Huerta. ${ }^{31}$ Aguilar

${ }^{29}$ El periódico oficial del gobierno provisional de Tabasco ilustraba así el clima de la junta: "En un favorable ambiente de optimismo se entró en diversas consideraciones[...] respecto a los postulados sociales y nacionalistas de nuestra gloriosa bandera de libertad, respecto a la situación de nuestro justo movimiento ante el fatuo gobierno imposicionista presidido dignamente por el traidor Álvaro Obregón y la injusta intromisión de los extranjeros. La Junta Militar de Frontera resolvió heroicamente defender la patria, que agoniza en las garras matricidas de los traidores", El Heraldo de ta Revolución, 20 de marzo de 1924.

${ }^{30}$ En efecto, don Adolfo había tenido una reunión en Nueva York con Zubarán, el general Alvarado y otros destacados jefes rebeldes, y resolvieron extender un nuevo nombramiento en favor de Alvarado, sin anular previamente el que se había ex̃pedido en favor de Aguilar. Prieto, Cincuenta,1968, p. 249.

31 "Nombramiento Alvarado jefe supremo ocasionará fracaso completo revolución sureste. Si no revócase inmeditamente dicho nombramiento, me consideraré en libertad para proceder como convenga. Yo le he ofrecido mi lealtad como jefe revolución, pero no me considero obligado subordinarme otra persona $[\ldots]$ para conmigo falta consideración [...] hoy que todo marchaba con éxito, cuando se había logrado la unificación completa de los elementos revolucionarios, cuando se estaba logrando moralizar la administración revolucionaria y se 
buscó en una primera instancia la definición de posiciones de los que se encontraban con él. Manuel Antonio Romero, gobernador de Tabasco, optó por mediar. Fue a Frontera a ver al general Alvarado y volvió a Villahermosa en busca del general Aguilar. A ambos se les dio una comida en la casa del general Fernando Segovia y juntos acordaron la creación de una zona militar para cada uno. El 11 de abril los jefes acordaron considerar la región del sureste como integrada por la Primera División que comprendía Tabasco y Chiapas, con Aguilar al frente, y la Segunda abarcando Campeche, Yucatán y Quintana Roo, con Alvarado. ${ }^{32}$

La reorganización de los alzados llegó, en todo caso, demasiado tarde, cuando el cerco gubernamental se estrechaba por tierra y el de la Marina de Estados Unidos por el Golfo. En anuncio del éxodo que luego vendría, Aguilar "recomendó" la salida hacia Mérida de los civiles, "por constituir un lastre

hacían grandes economías para fomentar la revolución, se cometió el desatino de extender nombramiento igual al que se me había otorgado, del cual no hice uso por considerarlo impolítico, ya que usted no tiene derecho para designar jefe de la revolución, ni aun interinamente, sino que es facultad exclusiva de todos los revolucionarios, generales, jefes y oficiales que están a mis órdenes en la tercera zona militar. Le exajo que inmediatamente se interne en territorio nacional para seguir acaudillando la revolución, o que de manera franca declare que no está dispuesto a seguir encabezando el movimiento que usted inició, para en tal caso nombrar en su lugar persona que sepa cumplir con su deber y con los compromisos contraídos por sus partidarios". Telegrama del general Cándido Aguilar a Adolfo de la Huerta, 11 de abril de 1924, en Taracena, Verdadera, 1992, pp. 421-422.

${ }^{32}$ Ibid., pp. $422-423$. muy grande para los jefes militares". ${ }^{33}$ Él, por su parte, apenas logró escapar a Guatemala en compañía de Rodolfo Brito Foucher, director interino de Gobernación del gobierno rebelde. A su paso por Mérida, tuvo lugar un altercado entre Aguilar y Palacios Macedo que fue muy revelador del punto al que habían llegado las diferencias entre los insurrectos a esa hora del crepúsculo. El general Aguilar le indicó que "para que quedara librecito" procediera a entregar todos los fondos disponibles a un señor Sánchez, hombre de las confianzas del militar. Al ceder la Tesorería del movimiento, quedaba un saldo de $\mathbf{4 0} 000$ dólares en caja. Aguilar "consideró estorboso e impracticable el transporte del efectivo que deseaba enviar a Estados Unidos, para dar un nuevo impulso a la revolución en el Norte", y ordenó, en cambio, que el saldo fuera cambiado por giros a la vista, sobre Nueva York, endosados en blanco. Nunca se conoció el destino final de estos fondos, lo que permite sospechar que quedaron en los pantalones de Cándido. "Invitado" por Aguilar a "seguir desde el Campeche mi suerte", decepcionado y sin dinero en los bolsillos, Palacios Macedo salió por la frontera con Belice hacia La Habana. Para poder emprender su marcha hacia el exilio, Palacios Macedo tomó algunos caballos, lo que provocó la ira del general Aguilar,

${ }^{33}$ Carta de Jorge Prieto Laurens, Otilio González, Manuel Dávalos Aragón, Miguel Palacios Macedo y otros, a los generales Alvarado y Cándido González, Mérida, 12 de abril de 1924, en APM. Carta de Jorge Prieto Laurens a Miguel Palacios Macedo, Mérida, 13 de abril de 1924, en ibid. 


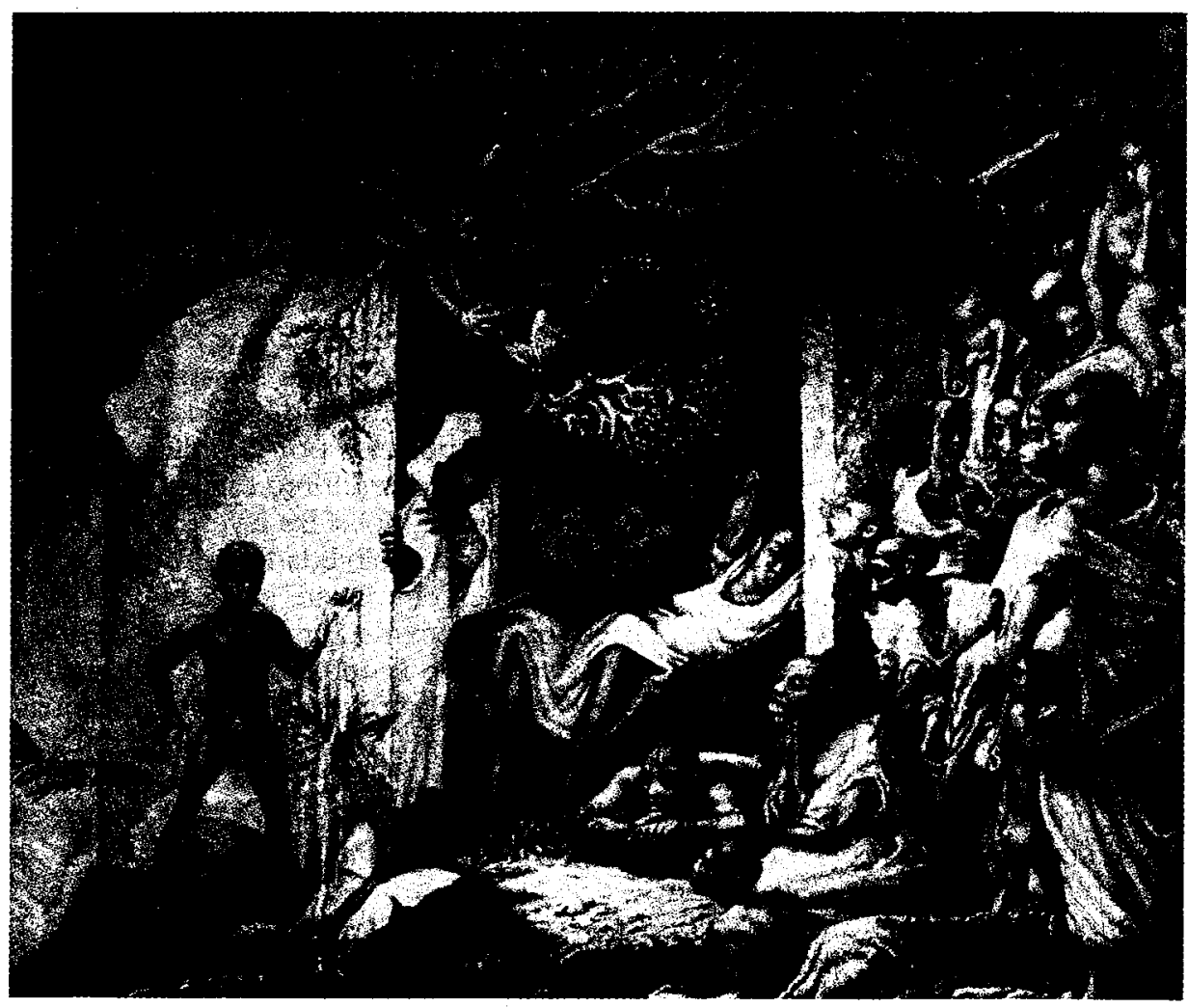

quien ordenó su aprehensión y fusilamiento en el acto donde se le encontrara, pero no vio cumplidos sus macabros deseos. ${ }^{34}$

El general Salvador Alvarado se trasladó por su cuenta, de Frontera a Villahermosa después del desembarco de una columna expedicionaria al mando del general Eugenio Martínez. Escu-

${ }^{34}$ Carta de Miguel Palacios Macedo a Adolfo de la Huerta, 11 de noviembre de 1924, en APM. Carta de Zubarán a De la Huerta, 3 de junio de 1924, en Monroy, Último, 1924, pp. 104-106. chó el rumor de que militares adictos a Aguilar se habían comprometido a desobedecer a Alvarado y a asesinarlo si era preciso. ${ }^{35}$ En este ambiente, Alvarado resolvió buscar el camino hacia los Altos de Chiapas para protegerse con el general Alberto Pineda Ogarrio. La reunión nunca tuvo lugar, porque Alvarado murió el 9 de junio en una celada a manos de hombres al mando del general Federico Aparicio, militar

35 Taracena, Historia, 1976, pp. 424-425. 
aguilarista, en un lugar conocido como "La Hormiga". ${ }^{36}$

Adolfo de la Huerta vivía por esos momentos clandestinamente en Estados Unidos, temeroso de su aprehensión por las autoridades, por lo que se vio impedido desde un principio para entrar en su actividad planeada en aquel país. El Departamento de Justicia mantenía un contacto estrecho con las autoridades mexicanas sobre el caso De la Huerta, pero resolvió no deportarlo cuando pudo hacerlo, quizá por las influencias que conservaba en el gobierno estadunidense, o porque podría ser considerado una pieza con importancia política para el futuro. En un primer momento pretendió llegar a las altas esferas de la vida política y económica en ese país, aprovechando sus contactos y experiencias a lo largo de la presidencia y como negociador de la deuda externa, pero no existen evidencias de que este propósito lo hubiera realizado de alguna manera. Para él, la batalla de la causa en Washington era "trascendentalísima". ${ }^{37}$

Sin embargo, los rebeldes se encontraron desde el principio con la "negativa absoluta" del gobierno de Estados Unidos para tratar con ellos. Zubarán, por su parte, conservaba la esperanza de un cambio eventual de política, da-

${ }^{36}$ Ibid., p. 429.

${ }^{37}$ Carta de De la Huerta a Zubarán, 19 de mayo de 1924, en Monroy, Último, 1924, p. 73. De la Huerta suponía que, en Estados Unidos, se recordaría de una manera favorable su trayectoria como gobernador de Sonora, presidente interino y secretario de Hacienda, y sugería a Álvarez del Castillo que recordara a la Casa Blanca su actuación durante esos cargos, Carta de De la Huerta a Zubarán Capmany, 27 de mayo de 1924, en ibid, pp. 73-74. das las tensiones existentes entre Washington y el nuevo gobierno de México. ${ }^{38}$ Consideraba, al igual que De la Huerta, que era indispensable abrir un nuevo frente por el norte, antes de diciembre de 1924, ya que después nada se podría hacer. ${ }^{39}$ En el noroeste estaba en los planes de invasión la Baja California, aventura en la que también participaban José María Maytorena, Esteban Cantú y Enrique Estrada, pero fueron descubiertos por la policía estadunidense, y este último cayó en la cárcel acusado de violar las leyes de neutrali$\mathrm{dad}^{40}$ Las posibilidades restantes quedaban en el noreste: en Tamaulipas estaban López de Lara y García Cavazos, y en Nuevo León, Antonio I. Villarreal y Pablo González; en Durango y Chihuahua, Chao, Hipólito Villa y Fernández. ${ }^{41}$

\section{El asesinato de Felipe CaRrillo PUERTO}

La rebelión delahuertista tuvo un capítulo especial en Yucatán que origi-

${ }^{38}$ Carta de Zubarán a Miguel Palacios Macedo, Nueva York, 22 de mayo de 1924, p. 2, en APM.

39 Ibid., p. 4.

${ }^{40}$ Carta de Cutberto Hidalgo a Zubarán, Los Ángeles, 11 de mayo de 1924, en Monroy, Último, 1924, p. 103; Prieto, Cincuenta 1968, pp. 283-284.

${ }^{41}$ El cónsul general de México en San Antonio informaba de las actividades de Pablo González, Antonio I. Villarreal, Alberto Salinas y César López de Lara "como una medida urgente" para salvar los intereses de la rebelión. Informe del cónsul general de México en San Antonio al secretario particular del presidente Fernando Torreblanca, 12 de febrero de 1924, en Archivo General de la Nación, fondo Obregón-Calles, 101-R2-I-1V, f. 2. 
nó una polémica que duró muchos años. Al estallar el movimiento en Veracruz, era jefe militar en el estado el coronel Ricárdez Broca, quien secundó la rebelión y aprehendió al gobernador Felipe Carrillo Puerto y a sus hermanos Benjamín, Edesio y Wilfrido, al presidente municipal de Mérida, Manuel Berzunza y otros. ${ }^{42}$ Alonso Capetillo escribió que las aprehensiones le fueron comunicadas a De la Huerta quien "contestó felicitando a Ricárdez Broca por tan importante captura, recomendándole que procediera con toda energía". Agregó que Ricárdez Broca interpretó la frase como la orden de pasar por las armas a los prisioneros y fraguó un consejo sumarísimo que empezó el 2 de enero de 1924, y concluyó el 3 en la madrugada. Los procesados fueron conducidos al $\mathrm{Ce}$ menterio General de Mérida y fusilados por tandas, cayendo en la primera Felipe Carrillo Puerto. Y

tan luego como se consumaron las ejecuciones, Ricárdez Broca lo comunicó a De la Huerta recibiendo contestación de "enterado", su ascenso al grado de general-brigadier y la ratificación de su nombramiento como gobernador provisional. ${ }^{43}$

Por cierto, Capetillo no da más prueba de lo anterior que su propia palabra. Lo que sí consta públicamente es que la acusación de que De la Huerta mandó asesinar a Carrillo Puerto en realidad partió de Obregón y Calles. Esta fue la

\footnotetext{
${ }^{42}$ Los últimos días de Carrillo y compañeros se encuentran detallados en Duarte, EFatalismo?, 1924.

${ }^{43}$ Capetillo, Rebelión, 1925, pp. 266-267.
}

afectada expresión teatral del presidente, en telegrama:

El asesino de Felipe Carrillo Puerto lleva el dolor a los hogares del proletariado y muchos millones de seres humanos; al recoger la noticia, sentirán rodar por sus mejillas lágrimas sinceras de dolor. Don Adolfo de la Huerta se dará cuenta de la magnitud de su crimen cuando recoja las protestas viriles del proletariado universal. La sangre generosa de Felipe Carrillo Puerto y companeros, es el testimonio de la apostastía de don Adolfo de la Huerta. ${ }^{44}$

\section{Y así habló el general Calles:}

[...] el verdadero asesino de Felipe Carrillo Puerto fue Adolfo de la Huerta, pues por informes verídicos que he recibido, sé que este cobarde traidor mandó la orden a Ricárdez Broca de que asesinara a Carrillo Puerto, por conducto del ex diputado Gustavo Arce, quien no trajo otra misión a este estado. Inmediatamente cumplida la orden de Ricárdez Broca, Arce regresó a Veracruz y días después fue premiado el autor material del asesinato, Ricárdez Broca, con el ascenso al grado inmediato superior en el ejército, concedido por el mismo De la Huerta [...]. ${ }^{45}$

La respuesta de Gustavo Arce a las acusaciones de Calles, fue una relación detallada de su experiencia desde Veracruz hasta Yucatán. El 24 de diciembre, De la Huerta le manifiestó que pensaba poner en libertad a los $\mathrm{Ca}$ -

${ }^{44}$ Citado en la carta del licenciado José Inés Novelo a Adolfo de la Huerta, 6 de enero de 1953, en AFDH.

${ }_{45}$ Declaración publicada en Excélsior, 5 de julio de 1924. 
rrillo y a sus seguidores y embarcarlos para el extranjero y, para protegerlos de ser victimados, se proponía hacerlos llevar a Veracruz. Arce embarcó en el primer vapor hacia Yucatán, con la consigna de De la Huerta de procurar con Ricárdez Broca que los detenidos fueran enviados al puerto. A Arce le pareció que Ricárdez estaba dispuesto a proceder en aquella forma, pero no lo hizo, en cambio lo engañó dando largas al asunto y le ocultó sus intenciones de convocar a consejo de guerra para juzgar a Carrillo y compañeros, hasta que Arce se enteró por la prensa local de los asesinatos. En algún momento, Arce visitó a Felipe Carrillo y le manifiestó en maya cuál era el propósito de De la Huerta, lo que "lo dejaba tranquilo" ${ }^{46}$ Uno de los aprehendidos con Carrillo Puerto y que luego fue liberado, señaló que Felipe tenía toda la confianza en la oferta de De la Huerta que le había sido transmitida por Arce. ${ }^{47}$

Adolfo de la Huerta dijo que se enteró de la aprehensión de Carrillo Puerto y compañeros no por los delahuertistas yucatecos, sino por el periodista

\footnotetext{
${ }^{46}$ Carta de Gustavo Arce al director de $E x$ célsior, Nueva Orleans, 9 de julio de 1924, en AFDH. Arce menciona algunos documentos cuyas copias se adjuntaron a la carta, tales como telegramas cruzados entre él y De la Huerta, un telegrama enviado a Agustín Vales Millet enviado desde Veracruz donde se exponía de manera clara la intención de De la Huerta de sacar a Carrillo Puerto y compañía de Yucatán para ser liberados posteriormente. Estos documentos, al parecer, ya se perdieron.

${ }^{47}$ Carta del profesor Eligio Erosa Sierra, secretario particular del gobernador Carrillo Puerto, al profesor Antonio G. Rivera, Villa Juárez, Pue., 17 de diciembre de 1949, en AFDH.
}

Carlos R. Menéndez, quien le envió un telegrama a Veracruz pidiéndole salvase la vida a Carrillo. El jefe supremo ordenó a Ricárdez Broca que remitiera a los presos a Veracruz; él contestó que carecía de medios de transporte para obedecer las órdenes, por lo que ante esta situación, De la Huerta envió al licenciado Arce para que rescatara a Carrillo Puerto y demás detenidos. ${ }^{48}$ De la Huerta llegó a pensar en algún momento que Ricárdez Broca, aunque estaba implicado con los demás militares, tenía una autoridad meramente nominal, carecía de mando de tropas y estaba supeditado en realidad a las decisiones de la Junta de Gobierno que constituían los jefes militares del 18 Batallón, cuyo control tenía el general Hermenegildo Rodríguez. ${ }^{49}$ La responsabilidad histórica del asesinato, sostenía De la Huerta, correspondía a los jefes y oficiales del 18 Batallón, y la mejor prueba de ello fue la publicación de un manifiesto tres días después de los hechos, donde ellos se echaron la responsabilidad de la muerte de los carrillistas. ${ }^{50}$ Así recibió De la

${ }^{48}$ Sosa, Crimen, 1969 , pp. 57-58.

${ }^{49}$ Don Adolfo sostenía así la inocencia de Rodríguez Broca: "El crimen no se habría perpetrado, de haberlo podido evitar él. Pero se rebeló contra él toda la oficialidad del $18 \mathrm{Ba}$ tallón, Hermenegildo Rodríguez en cápite. Y fue impotente para evitar el fatídico atentado. Y me afirma en esta convicción el hecho de que me hubiese enviado a Veracruz a uno de sus pocos amigos leales, quien sin arreos militares, se me presentó para exponerme la verdad de lo sucedido, y aclararme que su jefe, Ricárdez Broca, no había desobedecido mis órdenes, sino que quedó reducido a la impotencia para cumplirlas. Ibid., pp. 203-204.

50 " [...] ante la faz de la nación entera, asumimos la responsabilidad política, social e 


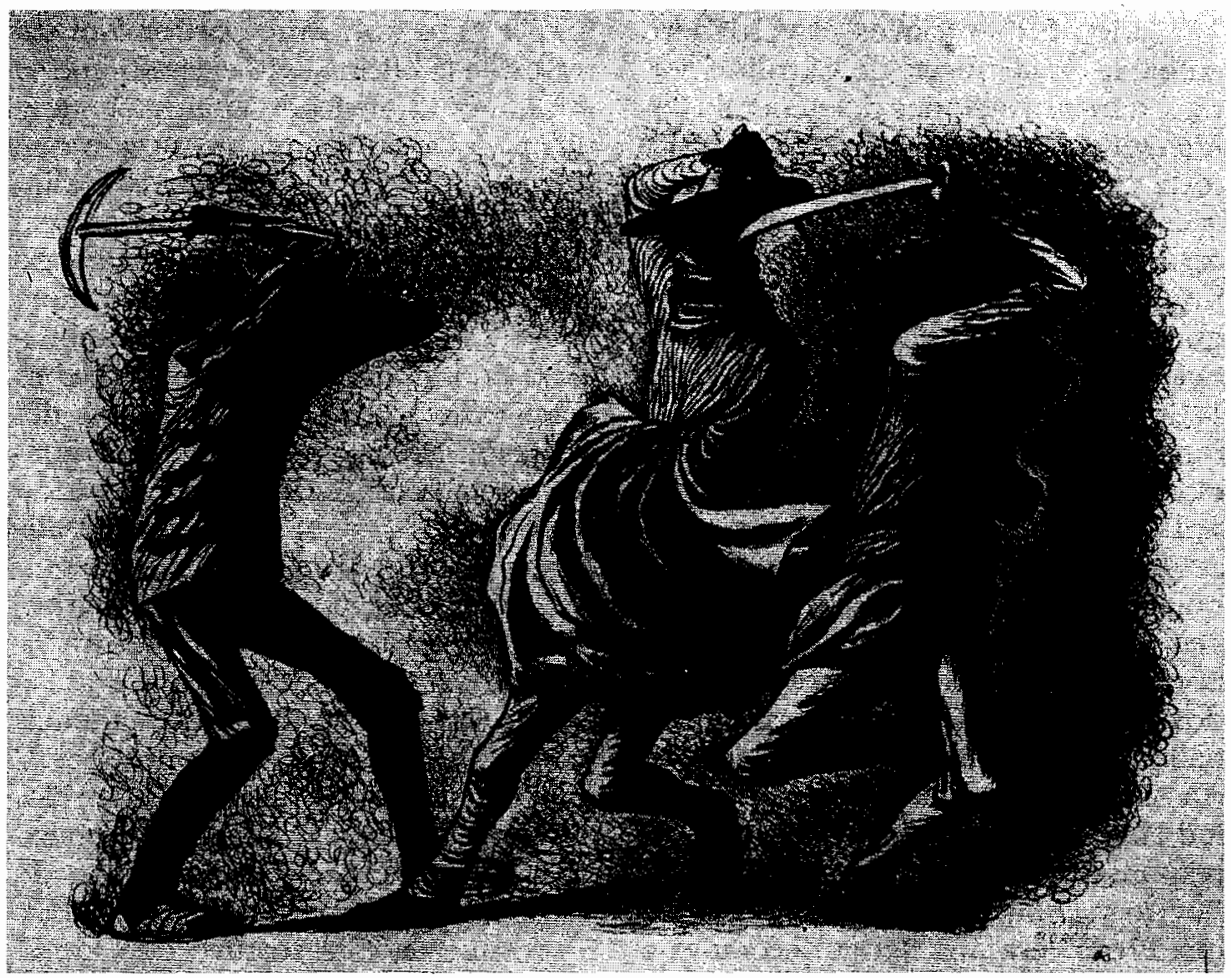

\section{Huerta la noticia del fusilamiento de los socialistas yucatecos:}

[...] cuando [Arce] me comunicó [la muerte de Carrillo y compañeros], llenándo-

histórica que con el tiempo pudiera exigirse, y en nombre de la justicia y el deber que norman nuestros actos, y sobreponiéndonos a los impulsos de nuestros corazones, pedimos que a los contumaces reos de tantos y tan grandes delitos, se les abriera un juicio sumarísimo para ser juzgados", edición extraordinaria del Diario Oficial del Gobierno del Estado de Yucatán, Mérida, 5 de enero de 1924. En dicho manifiesto no se encontraba el nombre de Ricárdez Broca ni tampoco el de Hermenegildo Rodríguez, Sol, Comunismo, s.a., p. 199. me de profunda amargura con la noticia, mi primer pensamiento fue castigar a los responsables de ese crimen tenebroso y empecé a mandar fuerzas que igualaran a las de Ricárdez Broca para poderlo aprehender, porque él estaba bastante fuerte con las que tenía y aunque fueron algunas, me vi precisado a movilizarlas para otros lados por las exigencias de la campaña, reservándome para más tarde el castigo de aquel crimen. ${ }^{51}$

${ }^{51}$ Relato de Adolfo de la Huerta al ingeniero Elías L. Torres, publicado en Jueves de Excélsior el 29 de abril de 1937, p. 28 . En él se consigna su creencia inicial de que Ricárdez Broca fue el responsable de los asesinatos. 
¿Quién fue entonces el verdadero culpable de la muerte de Carrillo Puerto? Están las versiones del general Hermenegildo Rodríguez. En 1940, evadió toda su responsabilidad en el fusilamiento, arrojando la culpa sobre Ricárdez Broca. ${ }^{52}$ Pero tres años antes habría relatado al periodista Hugo Sol que, cuando supo que De la Huerta había hecho lo imposible por salvar a Felipe y sus hermanos, "le olimos el queso y le chinchamos a su Carrillo Puerco". En otro momento, le relató a Sol que los militares estuvieron de acuerdo en el fusilamiento, no tanto por odio personal a Carrillo, sino a Calles y Obregón que habían provocado la revuelta: "nos lo echamos entre todos para fregar a Calles y Obregón, que nadie se raje". Por otro lado, Javier Marín Alfaro, secretario del Comité de Salud Pública que investigó y castigó a los responsables de la muerte de Carrillo Puerto y compañía, señaló que Ricárdez Broca "era una figura decorativa a quien no solamente no le obedecían, sino que se le imponían a lo que él ordenaba por mandato de la jefatura de la revolución". ${ }^{53}$

El relato de Hernán López Trujillo, juez instructor militar que asistió al consejo de guerra en que fueron sentenciados los carrillistas, sostuvo sin embargo, que la responsabilidad de Ricárdez Broca fue tanta como la de los demás. En la víspera de los acontecimientos trágicos, le escuchó decir de viva voz: "Ya que el pueblo yucateco quiere que se derrame sangre, así se

\footnotetext{
52 Escalante, "Culpable", 1940, p. 21.

53 Carta de Javier Marín Alfaro a don Adolfo de la Huerta, 16 de enero de 1950, en AFDH.
}

hará". Acto continuo, ordenó al director de la oficina del Telégrafo que se impidiera el envío de cualquier mensaje para De la Huerta, instrucción que se cumplió al pie de la letra; así los intentos de Gustavo Arce por avisar a su jefe de que el consejo de guerra estaba en marcha no tuvieron éxito. Aunque tanto Rodríguez Broca como Hermenegildo Rodríguez no firmaron el célebre manifiesto; estuvieron al pendiente del proceso. ${ }^{54}$ De la Huerta se negó, entonces, a establecer la capital de la rebelión en Mérida, como era lo indicado en términos políticos y militares; pero según declaró a su llegada a Estados Unidos, prefirió exponer el futuro del movimiento que ir a rodearse de los asesinos de Carrillo Puerto, quienes además habían desobedecido sus órdenes. ${ }^{55}$ Años después, la señora Elvia Carrillo, hermana de los asesinados de enero de 1924, reiteró el señalamiento de que De la Huerta era el responsable. ${ }^{56}$ En respuesta, éste sostuvo que fue el único que trató de rescatar a sus hermanos, y expresó su convicción de que los móviles de la repulsa de los yucatecos a su gobierno, fue ocasionada por causas distintas al delahuertismo. En esta misma réplica, él recordó el trato humanitario que dio a sus enemigos durante la rebelión. ${ }^{57}$

54 "Datos para la historia, cómo se verificó el llamado consejo de guerra que juzgó a don Felipe Carrillo Puerto y compañeros. La actitud. de los funcionarios de justicia militar", Nueva Orleans, 2 de mayo de 1924, en Bolio, Yucatán, 1967, pp. 60-61.

5s Ibid., p. 12; Alberto, "Felipe", 1930, p. 46.

${ }^{56}$ Últimas Noticias, 30 de julio de 1954.

57 "No tengo en mi conciencia ningún remordimiento por la muerte de alguien durante toda mi actuación revolucionaria. Hay cente- 
La rebelión delahuertista en Yucatán, fue en realidad, un conflicto de carácter local que enfrentaba a Felipe Carrillo Puerto y sus partidarios del Partido Socialista del Sureste contra los hacendados henequeneros y sus testaferros militares. En otras palabras, la "rara y discutida" filiación de los delahuertistas yucatecos tuvo que ver con una oportunidad favorable para alterar el equilibrio de fuerzas local. La mejor prueba de su "insularidad" estuvo en la desobediencia a una orden del jefe supremo de la rebelión que, claramente, carecía de cualquier autoridad sobre ellos y con quienes nunca tuvo mayor contacto, menos todavía después del asesinato de los Carrillo. De la Huerta no se cansó a lo largo de su vida de abominar del hecho, más todavía cuando él y Felipe se profesaban una larga amistad. Sobra decir además, que el involucramiento de los potentados yucatecos en el conflicto ni señaló tendencias ni marcó derroteros, pues en la rebelión participaron los grupos y las personalidades más diversas, de todas las posturas del espectro político. Lo mismo puede decirse de la coalición gubernamental.

En cuanto a alguna polémica acerca de la "personalidad criminal" de De la Huerta, que estuviera en el fondo del oprobioso asesinato de Carrillo Puerto

nares de supervivientes de aquellos acontecimientos, que salyaron su vida debido a mi actuación contraria a la pena de muerte y que, la mayor parte, unos amigos y otros enemigos personales míos, me guardan consideraciones por mi comportamiento con ellos. Yucatán no es una excepción en mi vida". Carta de respuesta de De la Huerta a las declaraciones de la señora Elvia Carrillo, Últimas Noticias, en AFDH. y compañía, el asunto concluiría si se planteara en los términos de su trayectoria humana y política. Difícilmente puede afirmarse que la conducta de Adolfo de la Huerta hacia sus enemigos durante el alzamiento, se haya diferenciado de la que tuvo a lo largo de su carrera política. Por ello, no es accidental que la lista de federales que perdieron la vida después de haber sido capturados, fuera mucho menor que la de los rebeldes ejecutados por sus enemigos. La implacable matanza de generales y de oficiales delahuertistas hecha por el gobierno, contrastó con el trato que se dispensaba a los militares que apresaban las fuerzas insurgentes. Ese mismo espíritu -virtud que amigos y enemigos le señalaron como un defecto- constó en el Manifiesto de De la Huerta en Veracruz que, al proclamar la abolición de la pena de muerte para los delitos de orden político, impuso a quienes secundaron esa protesta armada la obligación de respetar la vida de los prisioneros. Los casos más conocidos de perdón fueron los de los generales Vicente González y Miguel Henríquez Guzmán, cuyas vidas fueron preservadas por las órdenes que giró Adolfo De la Huerta, quien pidió además en reiterados telegramas a los generales tabasqueños, que no se atentara contra la existencia del gobernador Garrido Canabal y se le dejara libre. En Teocuitatlán, Jalisco, después de ser herido de gravedad por dos balazos en el pecho, el general Lázaro Cárdenas cayó prisionero de las fuerzas que mandaba el divisionario Enrique Estrada. A través de la estación inalámbrica de Veracruz, De la Huerta se comunicó a Guadalajara para ordenar 
que se atendiera a los heridos y se les impartieran las debidas garantías. También los generales Manuel y Maximino Ávila Camacho se salvaron del fusilamiento en Morelia porque oportunamente intervino en su favor el caudillo de la rebelión de 1923. De la Huerta se dirigió a los generales Manuel M. Diéguez y Enrique Estrada, responsabilizándolos personalmente de la vida de los prisioneros. ${ }^{58}$

\section{LA DISOLUCIÓN DEL MOVIMIENTO ORIGINAL EN EL EXILIO}

Hacia mayo de 1924, Rafael A. Frías, Adolfo Ferrer, Manuel Álvarez del Castillo y Antonio Manero se reunieron en Washington y dieron a Zubarán la dirección política "provisional" de la rebelión, con el encargo de dar nuevos lineamientos para el futuro. Ellos se basaban en un "programa de reorganización" del movimiento, al que De la Huerta, quien se encontraba de incógnito en algún lugar de Estados Unidos, nunca hizo algún comentario particular. Aunque no se tiene noticia del texto completo de dicho plan, sí se sabe que algunos de sus principios fueron el establecimiento del sistema parlamentario (vieja idea peleceana), la igualdad civil de mexicanos y extranjeros, el respeto absoluto a la propiedad privada y la implantación de un "agrarismo sin despojo" a base de irrigación, crédito agrícola e "inmigración rural". 59

58 Sosa, Crimen, 1969, pp. 100-102.

59 Telegrama de Luis Gaxiola a José Gaxiola, Nueva York, 22 de julio de 1924, en Monroy, Último, 1924, p. 144.
Conforme avanzaba 1924, el ánimo de los rebeldes tanto en México como en Estados Unidos iba en picada. César López de Lara y Pablo González, las últimas esperanzas para que el movimiento adquiriera fuerza, no alcanzaron a juntar los fondos necesarios para la la invasión por el noroeste. Para colmo, los rebeldes se mantenían en el exterior virtualmente incomunicados, a excepción del pequeño grupo que trabajaba en Washington y Nueva York: Zubarán, Álvarez del Castillo y Manero, cada vez más distantes del jefe supremo que vivía y viajaba por rumbos desconocidos. Ni el mismo Prieto Laurens comprendía la situación, envuelta en rumores de que De la Huerta se había retirado de la lucha y aceptado con ello la derrota. Al agradecer a Zubarán el nombramiento en su favor de jefe de propaganda y publicidad rebelde en Estados Unidos, Prieto expresó su esperanza de "un resurgimiento del jefe supremo", y pidió se le aclarase si seguía en pie el propósito de De la Huerta "de combatir a los traidores para que ninguno desmaye ni se desespere, a pesar de la crisis económica en que se encuentra la mayoría". ${ }^{60}$ La causa sufría, aparte de por la escasez crónica de recursos para operar, por los latrocinios de aquellos a quienes se les encomendaron tareas como la compra de armas. Uno de esos casos fue el doctor Carlos del Río, a quien el agente revolucionario Pérez Heredia acusó de robarse literalmente el dinero destinado a armamento y

${ }^{60}$ Prieto Laurens a Zubarán, en Rafael Zubarán a Adolfo de la Huerta, 12 de junio de 1924, en ibid., pp. 127-128. 
pertrechos. Los fondos menguaban sin remedio, y se esperaba que Palacios Macedo, tesorero del movimiento, se presentase con dinero en Nueva York, lo cual no ocurrió, porque Aguilar, como se dijo antes, guardó lo poco que quedaba. Mientras tanto, las traiciones y deserciones no se detenían. Llegó la hora de Froylán C. Manjarrez, el viejo amigo de De la Huerta,

quien le causó la impresión más dolorosa $[\ldots]$ aún no me pasa la pena tan honda que me ha ocasionado la delación de Froylán, como un traidor vulgar que se pasa al enemigo dándole el santo y seña del campo en donde ha militado. $^{61}$

El punto final de la alianza rebelde original fue puesto con el distanciamiento definitivo entre De la Huerta y la alianza Zubarán-Manero. Luis $\mathrm{F}$. Seoane, allegado a De la Huerta, lo puso en alerta de que habrían de darse instrucciones a Enrique Estrada, antes de que lo hiciese Zubarán, para "evitar que tienda así la red de la intriga que ha estado tendiendo perversamente en contra del delahuertismo". ${ }^{62}$ A esas alturas, De la Huerta criticaba con dureza a Antonio Manero por considerarlo deshonesto. ${ }^{63} \mathrm{Su}$ asociación con

${ }^{61}$ Carta de De la Huerta a Álvarez del Casti1lo, 25 de junio de 1924, en ibid., pp. 186-187.

${ }^{62}$ Carta de Luis Seoane a De la Huerta, Nueva Orleans, 8 de agosto de 1924, en ibid., pp. 145 y 147 .

${ }^{63}$ Una semblanza de Manero, "un banquero que no sentía aversión por los negocios turbios", en cuyo historial se habría encontrado la venta del archivo de la rebelión (en contubernio con el mismo Zubarán), se encuentra en Ruiz, México, 1984, pp. 206-207.
De la Huerta no era reciente pero sí intensa, a juzgar por las importantes comisiones que de él recibió. ${ }^{64}$ Manero tuvo a su disposición fuertes sumas de dinero sin que explicara nunca su destino final:

sé mucho más de lo que usted sabe -le dijo De la Huerta a Álvarez del Castillo$y$, por esta circunstancia, le estimaré a usted se sirva solicitar a él le entregue todas las credenciales y nombramientos que tiene de mí, pues no quiero tener ligas con este señor ni un minuto más. Si no devuelve las credenciales, me veré en el penoso caso de hacer declaraciones sobre su deslealtad y traición a nuestra causa, girando una circular sobre la nulificación de sus credenciales.

En la misiva, De la Huerta reconoció que sus relaciones con Zubarán y Manero estaban rotas desde principios de agosto de 1924. Se declaró ignorante de los programas de reorganización, "porque nada me han comunicado sobre el particular" y entendió que, de sus tratos con algunos correligionarios, se consideraba ya ajeno a ellos. A fin de no provocar escándalos con una

${ }^{64}$ Manero encabezaba desde 1920 la Comisión de Hacienda y Crédito Público en la Cámara de Diputados, y fue miembro de la Comisión de Estatutos del Banco de México en 1923. Con el patrocinio de De la Huerta, viajó por Estados Unidos y varios países europeos de octubre de 1922 a mayo de 1923, para familiarizarse, entre otras cosas, con el modelo de Banca central del Reischbank, sobre el que pensaba fincar el Banco Único de Emisión de México. "Informe sobre las comisiones desempeñadas en Estados Unidos, Inglaterra, Alemania y Suiza (octubre a mayo de 1922-1923", en AFDH; Carta de Antonio Manero a Adolfo de la Huerta, ministro de Hacienda y Crédito Público, en AFDH. 
pertrechos. Los fondos menguaban sin remedio, y se esperaba que Palacios Macedo, tesorero del movimiento, se presentase con dinero en Nueva York, lo cual no ocurrió, porque Aguilar, como se dijo antes, guardó lo poco que quedaba. Mientras tanto, las traiciones y deserciones no se detenían. Llegó la hora de Froylán C. Manjarrez, el viejo amigo de De la Huerta,

quien le causó la impresión más dolorosa [...] aún no me pasa la pena tan honda que me ha ocasionado la delación de Froylán, como un traidor vulgar que se pasa al enemigo dándole el santo y seña del campo en donde ha militado. $^{61}$

El punto final de la alianza rebelde original fue puesto con el distanciamiento definitivo entre De la Huerta y la alianza Zubarán-Manero. Luis $\mathrm{F}$. Seoane, allegado a De la Huerta, lo puso en alerta de que habrian de darse instrucciones a Enrique Estrada, antes de que lo hiciese Zubarán, para "evitar que tienda así la red de la intriga que ha estado tendiendo perversamente en contra del delahuertismo". ${ }^{62} \mathrm{~A}$ esas alturas, De la Huerta criticaba con dureza a Antonio Manero por considerarlo deshonesto. ${ }^{63}$ Su asociación con

${ }^{61}$ Carta de De la Huerta a Álvarez del Castillo, 25 de junio de 1924, en ibid., pp. 186-187.

${ }^{62}$ Carta de Luis Seoane a De la Huerta, Nueva Orleans, 8 de agosto de 1924, en ibid., pp. 145 y 147.

${ }^{63}$ Una semblanza de Manero, "un banquero que no sentía aversión por los negocios turbios", en cuyo historial se habría encontrado la venta del archivo de la rebelión (en contubernio con el mismo Zubarán), se encuentra en Ruiz, México, 1984, pp. 206-207.
De la Huerta no era reciente pero sí intensa, a juzgar por las importantes comisiones que de él recibió. ${ }^{64}$ Manero tuvo a su disposición fuertes sumas de dinero sin que explicara nunca su destino final:

sé mucho más de lo que usted sabe -le dijo De la Huerta a Álvarez del Castillo$y$, por esta circunstancia, le estimaré a usted se sirva solicitar a él le entregue todas las credenciales y nombramientos que tiene de mí, pues no quiero tener ligas con este señor ni un minuto más. Si no devuelve las credenciales, me veré en el penoso caso de hacer declaraciones sobre su deslealtad y traición a nuestra causa, girando una circular sobre la nulificación de sus credenciales.

En la misiva, De la Huerta reconoció que sus relaciones con Zubarán y Manero estaban rotas desde principios de agosto de 1924. Se declaró ignorante de los programas de reorganización, "porque nada me han comunicado sobre el particular" y entendió que, de sus tratos con algunos correligionarios, se consideraba ya ajeno a ellos. A fin de no provocar escándalos con una

${ }^{64}$ Manero encabezaba desde 1920 la Comisión de Hacienda y Crédito Público en la Cámara de Diputados, y fue miembro de la Comisión de Estatutos del Banco de México en 1923. Con el patrocinio de De la Huerta, viajó por Estados Unidos y varios países europeos de octubre de 1922 a mayo de 1923, para familiarizarse, entre otras cosas, con el modelo de Banca central del Reischbank, sobre el que pensaba fincar el Banco Único de Emisión de México. "Informe sobre las comisiones desempeñadas en Estados Unidos, Inglaterra, Alemania y Suiza (octubre a mayo de 1922-1923", en AFDH; Carta de Antonio Manero a Adolfo de la Huerta, ministro de Hacienda y Crédito Público, en AFDH. 
escisión pública, "dejemos que él (Zubarán) trabaje por su lado, independientemente de nuestras gestiones". 65

Zubarán, en efecto, siguió trabajando por su lado, hasta que en carta circular fechada el 27 de septiembre de 1924, declaró públicamente las razones de su rompimiento con De la Huerta. En exaltada manifestación de razones, elogió su propia labor realizada en Estados Unidos, la cual había incluido no solamente tratar de hacer variar la actitud norteamericana hacia los rebeldes, "sino justificar la ausencia del jefe supremo y proteger en lo posible su deteriorada imagen". ${ }^{66}$ Subrayó el tema de una reorganización del movimiento -su perenne obsesión- a base de impersonalismos, "que dé cabida a distintos grupos y tendencias revolucionarias sobre un pie de igualdad". Para este fin, recordó, se le nombró director político del movimiento con la encomienda de elaborar un nuevo plan para la rebelión y, al pedírsele una opinión, De la Huerta en lugar de respon. der suspendió toda correspondencia con él. Zubarán se quejó además de que De la Huerta se lo ocultó cuando visitó Nueva York, y lo acusó de actuar por encima de la dirección revolucionaria y de nombrar a Adolfo Ferrer je-

${ }^{65}$ Carta de De la Huerta a Álvarez del Castillo, 7 de agosto de 1924, en "Documentos del archivo de la rebelión de diciembre", El Universal, 3 de octubre de 1924.

66 " [...] he prevenido y corregido acres censuras para usted $[. .$.$] me he visto obligado a$ mentir a mis correligionarios y extraños para sostener y defender a usted, recibiendo diatribas porque no indicaba el lugar donde usted se encontraba y que nunca se sirvió confiarme". Carta de Zubarán a De la Huerta, 27 de septiembre de 1924, en Monroy, Último, 1924, p. 150. fe del movimiento, sin hacerlo siquiera de su conocimiento. ${ }^{67}$ Esta circular reconoció más que nada, la irrecuperable descomposición del liderazgo rebelde original, iniciada tiempo atrás como un intento del grupo de Nueva York de sustituir al jefe supremo por un cuerpo colegiado.

Zubarán criticó además el hecho de que, al comenzar a externarse el "carácter impersonalista del programa, los más adictos partidarios de don Adolfo llegaron al extremo de considerar al delahuertismo la causa, razón de ser y finalidad de la revolución", y a exhibir dicho plan como innecesario y tendiente a privarlo de la jefatura. ${ }^{68}$ Pero la gota que derramó el vaso fue un artículo publicado en un boletín en El Paso, en el sentido de que la causa rebelde tenía un traidor (Antonio Manero), quien le pasaba a su hermano (Enrique) la información transmitida a su vez a Obregón. En una línea similar, $L a$ Prensa de San Antonio publicó un manifiesto atribuido al general Pablo González, en el que se acusó a Zubarán y a Manero de haber robado los archivos de la revolución. ${ }^{69}$ Aislado casi por completo, Zubarán se hizo llamar "Alto comisionado de la Organización del Partido Nacional Revolucionario", y se le vio protestar contra el préstamo del banquero texano Arditt a Obregón. ${ }^{70}$

A fines de 1924, otra rama de una rebelión acéfala se secaba. El manifiesto del general Aguilar y sus juntas de San Antonio no llevaban a nada, y ha-

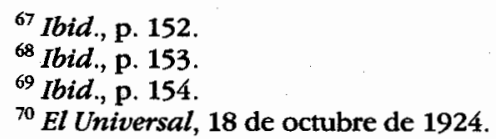




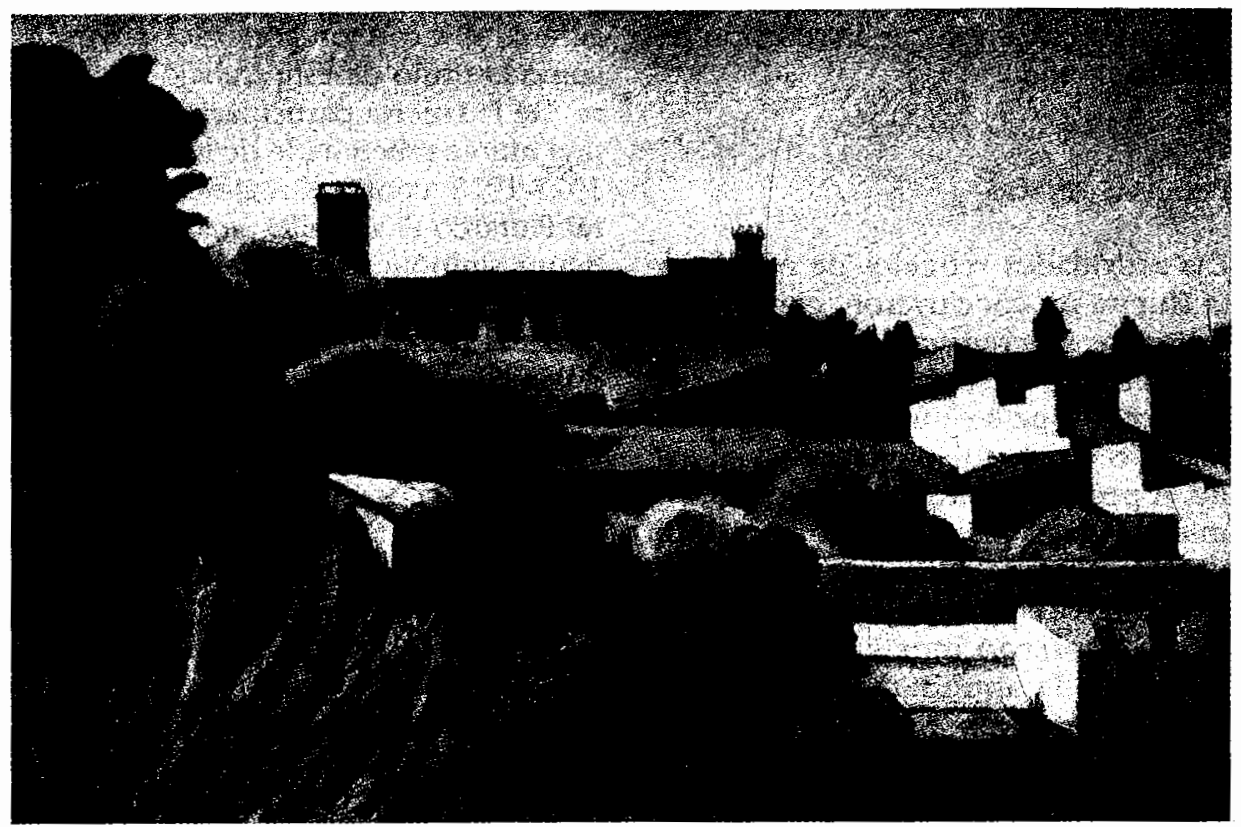

brían sido observadas por el gobierno a través de Juan Barragán. ${ }^{71}$ Dicho manifiesto, así como las reuniones penetradas por informantes, según Calcáneo Díaz, "inició un periodo de desaveniencias que puede ser funesto, pues rompe por completo la unión y la armonía que, en estos momentos de prueba para el movimiento, nos son tan necesarios". ${ }^{72}$ La desaparición del archivo de la rebelión y su posterior entrega al gobierno de México (no se llegó a sa-

${ }^{71}$ Se descubrió un telegrama enviado por el general Obregón al general Juan Barragán: "Enterado su atento mensaje en clave. Agradézcole sus informaciones. Afectuosamen te. A. Obregón", reproducido en carta sin firma, dirigido a Antonio Hernández Ferrer, 23 de septiembre de 1924, en AFDH.

${ }^{72}$ Carta de A. Calcáneo Díaz a De la Huerta, 10 de octubre de 1924, en AFDH. ber quién hizo ambas cosas), puso en evidencia el grado de debilidad y descomposición a que había llegado la jefatura insurrecta radicada en Estados Unidos. Alguna parte mínima fue publicada en la prensa de la ciudad de México en septiembre y octubre de 1924, y se incluyó en el apéndice del célebre libro de Monroy y Bautista, $L a$ rebelión sin cabeza. Expresándose con autocompasión, Calcáneo Díaz señaló que el contenido de este archivo sólo trataba "de la pobreza y de la miseria en que se encuentran un puñado de patriotas que tratan de reorganizarse noble y lealmente para salvar a su patria del infortunio a que la llevan sus malos hijos". ${ }^{73}$ La verdad absoluta en

${ }^{73}$ Ibid. 
esos momentos era que la rebelión había terminado.

\section{Palabras finales}

Las actividades rebeldes de Adolfo de la Huerta no concluyeron, como generalmente se cree, con la derrota del movimiento de 1923-1924. Tampoco es verdad que su nueva carrera como maestro de canto se inició con su exilio. A pesar de la liquidación del movimiento en el país, y de la disolución del liderazgo delahuertista tradicional, no renunció a su propósito de derrocar al gobierno mexicano, como lo evidencia la abundante documentación existente en el archivo personal de De la Huerta, acerca de su febril actividad para mantener vivo el movimiento en el exilio. Dejó su condición de inmigrante clandestino en Estados Unidos y se acogió a la protección del Departamento de Justicia, para no violar la Ley de Neutralidad estadunidense. Sin embargo, siguió acopiando fuerzas y apoyos, manifestándose en declaraciones ante la prensa y, en ocasiones, cuando era invitado como orador en clubes políticos y de servicio en ese país. Puso distancia de los demás exiliados, muchos de los cuales -Prieto Laurens entre ellos- continuaban conspirando $\mathrm{y}$ alentando nuevas rebeliones en el territorio nacional. No abandonó su proyecto de invadir México a través de Sonora y de hacer de tal estado el santuario de una nueva rebelión; la oportunidad se presentó cuando los yaquis se alzaron contra el gobierno a causa de la toma ilegal de sus tierras comunales para beneficio personal del general Álvaro Obregón y los suyos. Y como el título de este trabajo lo sugiere, De la Huerta participaría todavía en una última rebelión, la de los yaquis en 1927-1928, contra el régimen del general Plutarco Elías Calles, más como una figura simbólica que real. Aunque no ingresó en territorio nacional para ponerse al frente de los yaquis (derrotados a la postre), sí lo hizo su hermano el general Alfonso De la Huerta, quien fue aprehendido. y fusilado cerca de Nogales. A consecuencia de sus ligas con los yaquis rebeldes y de un supuesto intento de asesinato en perjuicio de Obregón, el gobierno de México buscó extraditarlo, proceso en que un gran jurado en Los Ángeles lo declaró inocente de los cargos. Casi inmediatamente después del asesinato del general Álvaro Obregón en La Bombilla, De la Huerta declaró el fin de sus actividades políticas en el exilio y dio comienzo a su vida como afamado maestro del bel canto en Hollywood, para noveles y consagrados.

\section{APÉNDICE}

MANIFIESTO DE LOS LÍDERES REBELDES ACERCA DE LA SALIDA DEL JEFE SUPREMO ADOLFO DE LA HUERTA DEL TERRITORIO NACIONAL, Frontera, TAB., 18 DE MARZO DE 1924

La nación está plenamente convencida de que, sin la vergonzosa ayuda que habría arrollado a los imposicionistas hoy traidores a la patria, y restablecido en todo el país la pureza de nuestras instituciones y el respeto a la soberanía nacional, la fortuna ha querido sin 
embargo que esta lucha se prolongue para que el tiempo y los acontecimientos definan terminantemente actitudes y posiciones; pero el valor y civismo del Ejército Libertador de los soldados de la república y de la patria, factores importantísimos para resolver el problema que nos agita, tendrían que imponerse los más grandes sacrificios si la actual campaña se sostuviera ya no solamente contra Álvaro Obregón y sus cómplices, sino contra la influencia estadunidense que amenaza tomar la forma de una intervención en nuestros asuntos de carácter enteramente nacional. Frente de esa situación, el jefe supremo, don Adolfo de la Huerta, después de agotar los recursos aconsejados por el talento y la buena voluntad de sus representantes en el extranjero y con el propósito levantado de ahorrar sacrificios y de que se conozcan las verdaderas tendencias de nuestro movimiento, resolvió trasladarse violentamente a Estados Unidos, embarcando al efecto para La Habana en este puerto el día 14 que nos rige y continuando de allí al punto de su destino. El señor De la Huerta seguramente sabrá plantear en breve plazo, ante el pueblo americano y ante el mundo entero, la verdadera situación de México destruyendo los prejuicios que existen en contra de la revolución y los escrúpulos indebidos que hoy sirven de base para apoyar a un gobierno, que si pudo tener un origen legítimo lo ha perdido hoy por sus trasgresiones constantes a la ley. El enemigo aprovechará este viaje del jefe supremo para lanzar las especies más absurdas; pero el pueblo de la República sabrá a qué atenerse rechazándolas con energía, y los soldados de la libertad se convencerán de que su caudillo ha tenido un nuevo gesto de cariño para ellos. Ésta es la ocasión propicia para ratificar nuestro credo genuinamente revolucionario, nuestro entusiasmo por los principios verdaderamente avanzados de la Constitución de 1917 y nuestra resolución firme y categórica de seguir practicándolos en cada palmo de terreno que conquistemos al enemigo. La jefatura de operaciones de esta zona, expedirá al efecto los decretos respectivos para encausar los procedimientos revolu. cionarios. Por otra parte, es necesario obrar con energía castigando severamente a los malos mexicanos que han solicitado la protección extranjera y, en algunos casos concretos, aun la ayuda de elementos de fuerza militar. Para esto se pondrá en vigor en la región del sureste la célebre ley de 25 de enero de 1862 y se invitará a los gobernadores y jefes revolucionarios para que la apliquen en sus respectivas jurisdicciones. Hacemos saber a la nación y a todos nuestros compañeros de lucha, que el sureste y el sur de la república continuarán en su puesto como estuvieron siempre en las campañas que el país ha sostenido en defensa de su independencia y de sus libertades. No vacilamos en creer que igual actitud guardarán nuestros demás compañeros de revolución, y aunque no pueden ser motivo de discusión nuestra firmeza de principios y nuestra resolución de continuar en esta lucha hasta el final, estimamos oportuno reafirmar nuestro criterio revolucionario y nuestra absoluta fe en el triunfo, en estos momentos en que Álvaro Obregón se envanece de pretendidos triunfos alcanzados 
por su ejército pretoriano. Mientras dure la ausencia del señor De la Huerta, los jefes militares continuaremos en nuestras respectivas zonas combatiendo sin descanso, y los civiles continuaremos igualmente dentro de nuestra esfera de acción sosteniendo los principios que nos obligaron a salir de la capital de la república antes de someternos a las amenazas o doblegarnos a las insinuaciones pérfidas de la tiranía obregonista. Soberanía Nacional y Constitución, en Frontera, Tabasco, a 18 de marzo de 1924. Gral. de División Cándido Aguilar, jefe de la 3a. Zona Militar. Gral. J. Adolfo Cadenas, Gral. Fernando Segovia, Gral. Eustorgio Vidal, Gral. Rodolfo H. Vivanco, Gral. Carlos Green, Gral. Alejandro Green, Gral. Pedro Hernández Torres, Gral. Ramón Mena, Gral. Faustino de la Rosa, Gral. Manuel Castillo Brito, Gral. Ricardo Reyes, Gral. Mariano Moreno Montero Villar, Gral. Guillermo Fernández, Gral. Valentín Fausto, Gral. Ignacio Gutiérrez, Gral. Ignacio Cuevas, Gral. Fernando M. Estrada; Gral. y Lic. Manuel Antonio Romero, gobernador provisional del estado de Tabasco; comodoro Manuel Camiro, comandante de la Marina de Guerra; capitán de fragata, Roberto Orduña; comandante del cañonero, teniente Fernández; segundo maquinista, Carlos Sansores, comandante del Azueta; Gral. y Dip. Onésimo Gonález, Dip. Lic. Otilio González, Corl. y Dip. Manuel Díaz Chávez, Tte. Corl. y Dip. José Ismael Aguado, Dip. Manuel Dávalos Aragón, Dip. José J. Raso, Dip. Gilberto Bosques, Jorge Prieto Laurens, gobernador constitucional del estado de San Luis Potosí; Lic. J. Rodríguez de la Fuente; Lic. Rodolfo Brito Foucher, encargado del Despacho del Departamento de Relaciones Interiores y Exteriores, Corl. Rafael Sánchez de la Vega; Tte. Corl. Ignacio Suárez; Mario Hernández, Srio. Part. del jefe supremo; Ángel Granados, Luis R. Suárez, Enrique González, mayor Domingo $C$. Duhalt.

\section{ARCHIVOS}

AFDH Archivo Familia De la Huerta. AGN Archivo General de la Nación. APM Archivo Miguel Palacios Macedo.

NAW The National Archives Department of State, Records of the Departament of State Relating to Internal Affairs of Mexico, 1910-1929, Record Group 59, Washington, D. C., 1959.

\section{Periódicos}

- Diario Oficial del Gobierno del Estado de Yucatán, Mérida, Yuc.

-Excélsior, México, D. F.

-El Heraldo de la Revolución, Villahermosa, Tab.

-El Universal, México, D. F.

-La Opinión, Los Ángeles.

-Últimas Noticias, México.

\section{Bibliografía}

-Alberto, Ernesto, "Felipe Carrillo Puerto", Crisol, México, D.F., enero de 1930.

- Betancourt Pérez, Antonio, El asesinato de Carrillo Puerto: refutación a las tesis sustentadas por el escritor don Roque Sosa Ferreyro en su libro El crimen del miedo, Imprenta Zamora; Mérida, $1974,57 \mathrm{pp}$.

-Bolio, Edmundo, Yucatán en la dictadura y la revolución, Instituto Nacional de Estudios Históricos de la Revolución Mexicana, México, 1967, 217 pp. 


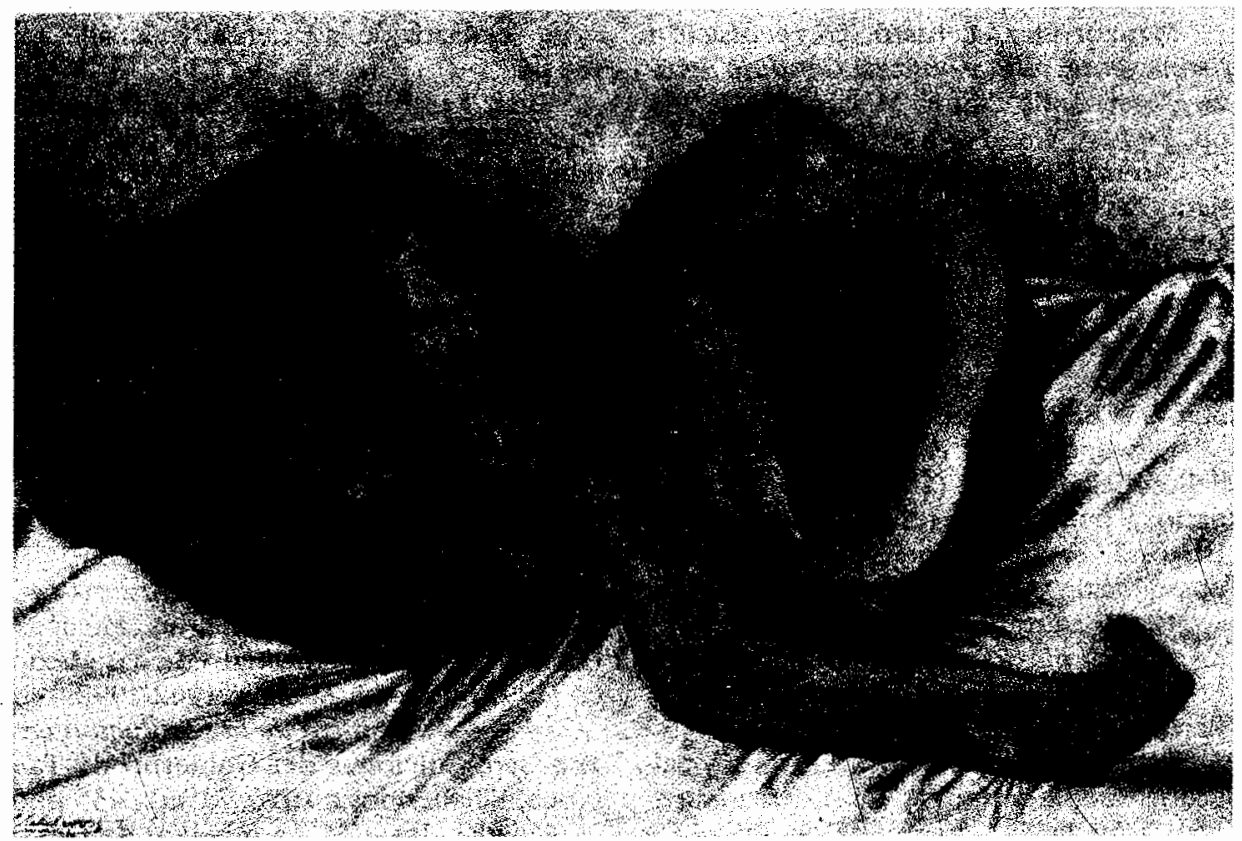

-Capetillo, Alonso, La rebelión sin cabeza: génesis y desarrollo del movimiento delabuertista, Imprenta Botas, Mexico, 1925, 318 pp.

-Castro Martínez, Pedro Fernando, "La intervención olvidada: Washington en la rebelión delahuertista", Secuencia. Revista de bistoria y ciencias sociales, Instituto Mora, núm. 34, enero-abril, 1996.

-Corzo Ramírez, Ricardo, José González Sierra, y David A. Skerrit, ...Nunca un desleal: Cándido Aguilar (1889-1960), El Colegio de México/Gobierno del Estado de Veracruz, México, 1986, 348 pp.

-Duarte, "Chato", EFatalismo...? Obra bistórica que contiene: el movimiento de labuertista en Yucatán; salida del gobernador Carrillo Puerto y compañeros; captura de éstos; consejo sumarísimo, sentencia y ejecuciones, s.e., s.a., marzo de 1924, $103 \mathrm{pp}$.
-Dulles, John W. F., Ayer en México, una crónica de la revolución mexicana, trad. Julio Zapata, Fondo de Cultura Económica, México, 1977, 652 pp.

-Escalante, Emilio. "El culpable del fusilamiento de los Carrillo Puerto", Todo, núm. 332, enero de 1940.

-Guzmán Esparza, Roberto, Memorias de don Adolfo de la Huerta, según su propio dictado, 2a. ed., Ediciones Guzmán, México, 1958, 33 pp.

-Joseph, Gilbert M., Revolución desde afuera: Yucatán, México y los Estados Unidos 1880-1924, trad. Eduardo L. Suárez, Fondo de Cultura Económica, México, 1992, $382 \mathrm{pp}$.

-López Portillo, Fernando, "Recuerdos de la Revolución Mexicana, 1923: la rebelión delahuertista XXVII", Sucesos Para Todos, septiembre 7 de 1954. 
-Manzur Ocaña, Justo, La revolución permanente: vida y obra de Cándido Aguilar, Costa-Amic Editor, México, 1972, 364 pp.

-Monroy Durán, Luis y Gonzalo Bautista, El último caudillo, José S. Rodríguez, Mérida, 1924, 15 pp., ils.

-Paoli, Francisco José, Yucatán y los origenes del nuevo estado mexicano: gobierno del general Salvador Alvarado 19151918, Ediciones Era, México, 1984, 222 pp., mapas (Colección Problemas de México).

-Plascencia de la Parra, Enrique, "La rebelión delahuertista (1923-1924): sus escenarios y personajes", tesis de doctorado en Historia, Facultad de Filosofía y LetrasUNAM, México, 1996.

-Prieto Laurens, Jorge, Cincuenta años de politica mexicana: memorias politicas, Editora Mexicana de Periódicos, Libros y Revistas, S. A., México, 1968, 432 pp.

-Prieto, Luis R., Guillermo Ramos, y Salvador Rueda (comps.), Un México a través de los Prieto: cien años de opinión y participación política, Centro de Estudios de la Revolución Mexicana Lázaro Cárdenas, A. C., México, 1987, 697 pp.

-Ramírez Garrido, Calixto, General Salvador Alvarado: un bombre en la revolu- ción, Secretaría de la Defensa Nacional, s.a., 164 pp.

-Ruiz, Ramón Eduardo, La gran rebelión 1905/1924, trad. José Luis González, Ediciones Era, México, 1984, 444 pp.

-Sol, Hugo (pseudónimo del periodista Víctor Manzanilla), El comunismo en México: quiénes lo incubaron y quiénes lo propalan, también titulado El comunis-mo en México y el arcbivo de Carrillo Puerto, 2a. ed., s.e., s.a., 215 pp.

-Sosa Ferreyro, Roque, El crimen del miedo: reportaje bistórico, cómo y por qué fue asesinado Felipe Carrillo Puerto, B. Costa-Amic Editor, México, 1969, 137. pp.

-Taracena, Alfonso, La verdadera re. volución mexicana, Editorial Jus, México; (1962) 12 vols., y Editorial Porrúa, México (1992), 12 vols., México, 1962-1992.

, Historia de la revolución en Tabasco, Ediciones del Gobierno de Tabasco, Villahermosa, 1976, 2a. ed., 435 pp.

-Valadés, José C., "La rebelión de Occidente: la rebelión delahuertista, con testimonios del general Enrique Estrada", inédito, $36 \mathrm{pp}$.

- "Memorias de Jorge Prieto Laurens", manuscrito inédito. 